\title{
Article \\ Sensitivity of Green-Up Date to Meteorological Indicators in Hulun Buir Grasslands of China
}

\author{
Jian Guo ${ }^{1,2}$, Xiuchun Yang ${ }^{3, *}$, Weiguo Jiang ${ }^{1,2} \mathbb{D}$, Fan Chen ${ }^{4}$, Min Zhang ${ }^{3}$, Xiaoyu Xing ${ }^{3,5}$, Ang Chen ${ }^{3}$, \\ Peng Yun ${ }^{6}$, Liwei Jiang ${ }^{7}$, Dong Yang ${ }^{5}$ (D) and Bin $\mathrm{Xu}^{5}$
}

check for updates

Citation: Guo, J.; Yang, X.; Jiang, W.; Chen, F.; Zhang, M.; Xing, X.; Chen, A.; Yun, P.; Jiang, L.; Yang, D.; et al. Sensitivity of Green-Up Date to Meteorological Indicators in Hulun Buir Grasslands of China. Remote Sens. 2022, 14, 670. https://doi.org/ $10.3390 /$ rs 14030670

Academic Editor: Maria

Laura Carranza

Received: 8 December 2021

Accepted: 28 January 2022

Published: 30 January 2022

Publisher's Note: MDPI stays neutral with regard to jurisdictional claims in published maps and institutional affiliations.

Copyright: (C) 2022 by the authors. Licensee MDPI, Basel, Switzerland. This article is an open access article distributed under the terms and conditions of the Creative Commons Attribution (CC BY) license (https:// creativecommons.org/licenses/by/ $4.0 /)$.
1 State Key Laboratory of Remote Sensing Science, Faculty of Geographical Science, Beijing Normal University, Beijing 100875, China; guojian@bnu.edu.cn (J.G.); jiangweiguo@bnu.edu.cn (W.J.)

2 Beijing Key Laboratory for Remote Sensing of Environment and Digital Cities, Faculty of Geographical Science, Beijing Normal University, Beijing 100875, China

3 School of Grassland Science, Beijing Forestry University, Beijing 100083, China; zhangmin_rs@bjfu.edu.cn (M.Z.); 82101185223@caas.cn (X.X.); chenang0226@bjfu.edu.cn (A.C.)

4 Academy of Agricultural Planning and Engineering, Ministry of Agriculture and Rural Affairs, Beijing 100125, China; chenfan1@aape.org.cn

5 Key Laboratory of Agri-Informatics, Ministry of Agriculture and Rural Affairs, Institute of Agricultural Resources and Regional Planning, Chinese Academy of Agricultural Sciences, Beijing 100081, China; yangdong@caas.cn (D.Y.); xubin@caas.cn (B.X.)

6 Region Ecological Environment Publicity and Education Center, Inner Mongolia Department of Ecology and Environment, Hohhot 010011, China; yunpeng1209@gmail.com

7 Academy of Inventory and Planning, National Forestry and Grassland Administration, Beijing 100714, China; jiangliwei0816@gmail.com

* Correspondence: yangxiuchun@bjfu.edu.cn

\begin{abstract}
Temperature and precipitation are considered to be the most important indicators affecting the green-up date. Sensitivity of the green-up date to temperature and precipitation is considered to be one of the key indicators to characterize the response of terrestrial ecosystems to climate change. We selected the main grassland types for analysis, including temperate steppe, temperate meadow steppe, upland meadow, and lowland meadow. This study investigates the variation in key meteorological indicators (daily maximum temperature $\left(\mathrm{T}_{\max }\right)$, daily minimum temperature $\left(\mathrm{T}_{\min }\right)$, and precipitation) between 2001 and 2018. We then examined the partial correlation and sensitivity of green-up date (GUD) to $\mathrm{T}_{\max }, \mathrm{T}_{\min }$, and precipitation. Our analysis indicated that the average GUD across the whole area was DOY 113. The mean GUD trend was -3.1 days/decade and the $25 \%$ region advanced significantly. $\mathrm{T}_{\max }$ and $\mathrm{T}_{\min }$ mainly showed a decreasing trend in winter $(p>0.05)$. In spring, $\mathrm{T}_{\max }$ mainly showed an increasing trend $(p>0.05)$ and $\mathrm{T}_{\min }$ a decreasing trend $(p>0.05)$. Precipitation showed no significant $(p>0.05)$ change trend and the trend range was $\pm 10 \mathrm{~mm} /$ decade. For temperate steppe, the increase in $\mathrm{T}_{\min }$ in March promotes green-up (27.3\%, the proportion of significant pixels), with a sensitivity of -0.17 days $/{ }^{\circ} \mathrm{C}$. In addition, precipitation in April also promotes green-up $(21.7 \%)$, with a sensitivity of -0.32 days $/ \mathrm{mm}$. The GUDs of temperate meadow steppe $(73.9 \%)$, lowland meadow $(65.9 \%)$, and upland meadow $(22.1 \%)$ were mainly affected by $\mathrm{T}_{\text {min }}$ in March, with sensitivities of -0.15 days $/{ }^{\circ} \mathrm{C},-0.13$ days $/{ }^{\circ} \mathrm{C}$, and -0.14 days $/{ }^{\circ} \mathrm{C}$, respectively. The results of this study reveal the response of vegetation to climate warming and contribute to improving the prediction of ecological changes as temperatures increase in the future.
\end{abstract}

Keywords: green-up date; phenology; greening; sensitivity; climate change; meteorological indicators; Hulun Buir; grassland

\section{Introduction}

Global temperatures continue to warm as a component of climate change, which affects many ecological patterns [1]. Phenology is the study of the development of plant and animal behavior throughout the year [2]. Myneni [3] found that in the context of global 
warming, plant phenology has undergone profound changes and has become a sensitive indicator of global change [4]. Climate change alters the time of phenological events [5,6], which may disrupt seasonal interactions between species, thereby affecting biodiversity and ecosystem primary production $[7,8]$. To quantify the response of green-up date (GUD) to climate change, it is increasingly important to pay attention to the interannual variation of GUD relative to the temperature/precipitation change per unit, which is called the temperature/precipitation sensitivity (days $/{ }^{\circ} \mathrm{C}$ or days $/ \mathrm{mm}$, respectively) [9-11]. From 1956 to 2006 , the daily minimum temperature $\left(\mathrm{T}_{\min }\right)$ of the global land surface increased faster than that of the daily maximum temperature $\left(T_{\max }\right)$. Such asymmetric warming patterns may result in important biological trends, especially in basic ecosystem metabolic processes, such as photosynthesis and respiration, which are sensitive to temperature changes [12]. Therefore, nighttime warming may have a greater effect on respiration than diurnal warming on photosynthesis. Most importantly, sensitivity is considered to be one of the key indicators to characterize the response of terrestrial ecosystems to climate change, and understanding the sensitivity of GUD to temperature can greatly improve our ability to predict ecological changes as temperatures increase in the future $[13,14]$.

Temperature is considered to be a convenient descriptor of temperate and cold zone vegetation distribution [15]. Several studies have shown that climate warming in recent decades has caused spatio-temporal changes in GUD, with the magnitude varying regionally and globally [3,5,16-22]. $\mathrm{T}_{\max }$ and $\mathrm{T}_{\min }$ have different changes and different effects on phenology [23-25]. A recent study found that an increase in $\mathrm{T}_{\max }$ had a greater effect on GUD than an increase in $T_{\min }$ in central Europe. In the past few decades, $T_{\min }$ has increased faster than $\mathrm{T}_{\max }$ during the day in most parts of the world, leading to a reduction in diurnal thermal amplitude [1]. $T_{\max }$ is more relevant than $T_{\min }$ for leaf development because photosynthesis only occurs in the daytime and plays a greater role in plant carbon fixation and plant green-up [26].

Researchers have found that ground-based observations [9-11,27], remote sensing data [28,29], or flux data [30] show great variability in temperature sensitivity in the grassland types of different regions. In eastern Canada, a warming experiment on Picea mariana at 20 different locations showed that both daytime and nighttime warming promoted bud growth, with daytime warming being more conducive to germination than nighttime warming [31]. In the Qinghai-Tibet Plateau, the increase in $\mathrm{T}_{\min }$ can significantly $(p<0.05)$ advance vegetation green-up at both species and regional scales. However, $\mathrm{T}_{\max }$ had no significant effect on GUD $(p>0.1)$ [32]. Compared with the cold Tibetan Plateau, China's temperate grasslands regions are warmer and drier, with a predominantly arid and semiarid climate. To understand the mechanisms by which temperature influences vegetation greening, it is important to study the separate effects of daytime and nighttime warming on vegetation GUD in temperate grasslands in China. A study had studied the asymmetric effects of daytime and nighttime warming on spring phenology in the temperate grasslands of China based AVHRR NDVI [24]. Therefore, it is necessary to use higher spatial resolution remote sensing data for high precision research.

Hulun Buir is a grassland system with the highest latitude in China. The grasslands in the southwest are semi-arid. The temperate meadow steppe (TMS) area is distributed on the west side of the Great Khingan Mountains and is the most common type of TMS area in China. The spatial heterogeneity of the hydroclimatic conditions determines the vegetation distribution in the Hulun Buir grassland. In arid/semi-arid areas, water is critical for plant growth, because soil moisture is usually not optimal.

It is often observed that vegetation activity at high elevations is mainly influenced by temperature changes, whereas plant growth at low elevations is often limited by water stress [33]. This view needs to be further examined in the Hulun Buir grassland. In addition, snowmelt in some high-altitude ecological areas in spring, such as in the Qinghai-Tibet Plateau, and often provides important supplementary water resources, thus influencing the spring vegetation development [34]. Winter precipitation plays an important role in regulating the spring vegetation phenology of water-deficient biomes in temperate steppe 
(TS) and temperate desert of China [35]. In arid and semi-arid areas of northeast China, the dates of phenological events are most significantly correlated with precipitation in the previous 2-4 months [36]. The GUD of the frozen soil in Inner Mongolia is mainly dominated by early autumn and winter precipitation, and the frozen soil plays an important role in storing the available water for subsequent vegetation green-up [37]. In the Hulun Buir TS and TMS regions, the annual average temperature is lower, with more than half of the regional annual average temperatures below $0{ }^{\circ} \mathrm{C}$ [38]. Usually, the soil surface is covered with snow in winter and the spring temperature increases lead to the spring snowmelt, which may have positive effects on GUD, but for which additional research is necessary.

Our present research focuses on the Hulun Buir grassland for two main reasons. First, this grassland is distributed in the extreme northeast portion of China across humid, subhumid, and semi-arid areas. Second, Hulun Buir is the most representative area of TMS in China. Our study has three main aims: (1) describe the variation in $\mathrm{T}_{\max }, \mathrm{T}_{\min }$, and precipitation in winter and spring; (2) quantify the partial correlation between GUD and $\mathrm{T}_{\max }, \mathrm{T}_{\min }$, and precipitation; and (3) determine the sensitivity of different grassland type GUD to $\mathrm{T}_{\max }, \mathrm{T}_{\min }$, and precipitation.

\section{Materials and Methods}

\subsection{Study Area}

The Hulun Buir Grassland is located at the middle latitudes of Eurasia, distributed in the northern temperate zone and a small part of the cold temperate zone-the highest latitude grassland area in China. Hulun Buir is distributed in the northeast of Inner Mongolia, forming the most concentrated TMS in China. Yet, it is also a typical grassland area, where a variety of meadow steppe ecosystems are found (Figure 1). It is an important part of the steppe sub-region of central Asia in the Steppe region of Eurasia, with rich grassland types. Precipitation gradually decreases from east to west, and the gradients in vegetation biomass are obvious. From east to west, the grassland shifts from a typical semi-arid climate through the meadow steppe, and the ecological geographical gradient changes from east to west with the dryness of the climate. Detailed information on the vegetation, topography, and climate are given in Guo et al. [38]. Based on an analysis of the entire study area, we selected TS, TMS, lowland meadow (LM), and upland meadow (UM) for a more detailed analysis.

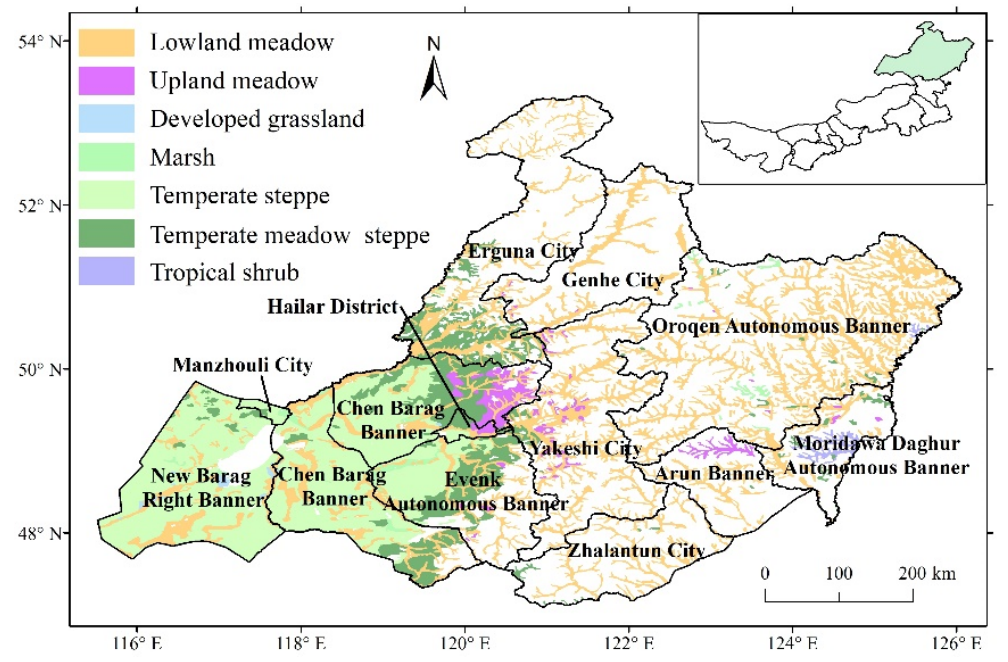

Figure 1. Administrative divisions and grassland classifications in Hulun Buir [38]. In this figure, the county boundaries were used to divide the different districts. The name of each administrative district is given in bold. The blank areas represent non-grassland areas. 


\subsection{Determination of Vegetation Green-Up Date}

Remote sensing data were derived from Moderate Resolution Imaging Spectroradiometer (MODIS) MOD09A1 data (2001-2018) of the National Aeronautics and Space Administration (NASA) https: / / modis.gsfc.nasa.gov / (18 September 2019). The MOD09A1 dataset was produced at a spatial resolution of $500 \mathrm{~m}$ and a temporal resolution of 8 days. Annual vegetation GUD on Hulun Buir grassland was determined from the normalized difference phenology index (NDPI). The NDPI was developed to minimize the effects of snowmelt [39]. NDPI is a sensitive indicator of vegetation growth and is thus widely used to derive GUD $[38,39]$.

$$
\mathrm{NDPI}=\frac{\rho_{\text {NIR }}-0.74 \times \rho_{\text {red }}+0.26 \times \rho_{\text {SWIR }}}{\rho_{\text {NIR }}+0.74 \times \rho_{\text {red }}+0.26 \times \rho_{\text {SWIR }}}
$$

where $\rho_{\text {NIR }}, \rho_{\text {red }}, \rho_{\text {SWIR }}$ represents the reflectance of the near-infrared band, red band, and shortwave-infrared, respectively.

For processing, the NDPI time series were filtered with a double logistic function, as described in Guo et al. [38]. After that, we determined GUD from the pre-processed MODIS NDPI using the median method. The median method was used to monitor the annual green-up date. The formula used is given below:

$$
\mathrm{NDPI}_{\text {mid }}=\left(\mathrm{NDPI}_{\max }+\mathrm{NDPI}_{\text {min }}\right) \times 50 \% \text {, }
$$

where NDPI ${ }_{\text {mid }}$ represents the NDPI of the green-up date, NDPI ${ }_{\max }$ represents the maximum NDPI throughout the growing season, and $\mathrm{NDPI}_{\min }$ represents the minimum of the NDPI increase phase.

\subsection{Calculation of the Key Meteorological Indicators}

The meteorological data (2000-2018) used in this study included temperature, precipitation, and insolation data downloaded from the China Meteorological Forcing Dataset [40], with a spatial resolution of $0.1^{\circ}$ and a temporal resolution of $3 \mathrm{~h}$. Meteorological data were resampled from $0.1^{\circ}$ to $500 \mathrm{~m}$ using the bilinear interpolation method in Envi5.3 software (Exelis Visual Information Solutions, Broomfield, United States). The advantages are that the method is simple and the processing speed fast.

$\mathrm{T}_{\max }, \mathrm{T}_{\min }$, precipitation, and insolation were chosen for the key meteorological indicators. In this study, we used temperature data with a resolution of $3 \mathrm{~h}$ for calculations of the daily maximum temperature and daily minimum temperature. Then, $T_{\max }$ was calculated by the mean of the daily maximum temperature in one month or one season, and $\mathrm{T}_{\min }$ was calculated by the mean of the daily minimum temperature in one month or one season. Precipitation was calculated by the sum of the precipitation in one month or one season, and insolation was represented by the mean of the downward shortwave radiation in one month or one season. According to the local climate of Hulun Buir, we chose spring (March, April, and May) and winter (January, February, and December of last year) for this study.

\subsection{Trend Analysis Method}

The Mann-Kendall [41,42] method was used to examine the trends in the green-up date and meteorological indicators. Since the Mann-Kendall method is a nonparametric test for monotonic trends, it does not assume a specific distribution for the data and is insensitive to outliers. The Mann-Kendall method was a climate diagnosis and prediction technology. It could determine whether there was a mutation in the time series, and if there was, the time of the mutation can be determined. The Theil-Sen method is a nonparametric statistical method for the significance test of the trend [43]. It is a method for robust linear regression that chooses the median slope among all lines through pairs of two-dimensional sample points. Combining the two is an excellent method for time series 
trend analysis, which has been widely used in climate and hydrological trend research in recent years [44-46].

\subsection{Partial Correlation}

A partial correlation method was used to investigate the influence of $\mathrm{T}_{\max }, \mathrm{T}_{\min }$, and precipitation on the interannual variation of GUD. A partial correlation analysis refers to the process when two variables are related to the third variable at the same time, the influence of the third variable is removed, the correlation degree between the other two variables is analyzed, and the determination index is the value of the partial correlation coefficient. This method has been successfully applied to eliminate the covariate effect between multiple influencing factors $[38,47,48]$. Suppose there are variables $x_{1}, x_{2}, \ldots$, $x_{n}(\mathrm{n}>2)$, then the partial correlation coefficients of any two variables $x_{i}$ and $x_{j}$ can be calculated as follows:

$$
r_{i j \cdot l_{1} l_{2} \ldots l_{g}}=\frac{r_{i j \cdot l_{1} l_{2} \ldots l_{g-1}}-r_{i l_{g} \cdot l_{1} l_{2} \ldots l_{g-1}} r_{j l_{g} \cdot l_{1} l_{2} \ldots l_{g-1}}}{\sqrt{\left(1-r_{i l_{g} \cdot l_{1} l_{2} \ldots l_{g-1}}^{2}\right)\left(1-r_{\left.j l_{g} \cdot l_{1} l_{2} \ldots l_{g-1}\right)}^{2}\right.}}
$$

where $l_{1}, l_{2}, \ldots, l_{g}$ represents variables other than $x_{i}$ and $x_{j}, r_{i j \cdot l_{1} l_{2} \ldots l_{g}}$ indicates the partial correlation coefficient between $x_{i}$ and $x_{j}$ when controlling variables $l_{1}, l_{2}, \ldots, l_{g} . r_{i j} \cdot l_{1} l_{2} \ldots l_{g-1}$ indicates the partial correlation coefficient between $x_{i}$ and $x_{j}$ when controlling variables $l_{1}$, $l_{2}, \ldots, l_{g-1} \cdot r_{i l_{g} \cdot l_{1} l_{2} \ldots l_{g-1}}$ indicates the partial correlation coefficient between $x_{i}$ and $l_{g}$ when controlling variables $l_{1}, l_{2}, \ldots, l_{g-1} \cdot r_{j l_{g} \cdot l_{1} l_{2} \ldots l_{g-1}}$ indicates the partial correlation coefficient between $x_{j}$ and $l_{g}$ when controlling variables $l_{1}, l_{2}, \ldots, l_{g-1}$.

\subsection{Sensitivity Analysis}

The sensitivity of vegetation GUD to temperature or precipitation is defined as the slope of a linear regression model of temperature or precipitation to GUD over a certain period, which describes the change in the GUD date per unit change of temperature and precipitation [49]. Sensitivity is an important parameter to measure the response of GUD to future climate change. The sensitivity calculation formula is as follows:

$$
\mathrm{Y}=\mathrm{aX}+\mathrm{b}
$$

where $\mathrm{Y}$ is the GUD of vegetation, $\mathrm{X}$ is a meteorological factor (daily maximum temperature, daily minimum temperature, and precipitation in winter, spring, or one month), $\mathrm{b}$ is a constant, and a is the sensitivity of GUD to meteorological indicators.

This study calculated the sensitivity of vegetation GUD to meteorological indicators from 2001 to 2018, including the daily maximum temperature, daily minimum temperature, and precipitation, and analyzed different grassland types and periods to better understand the response of vegetation to climate change.

\subsection{Flow Chart}

A flow chart of the key indicators computation and statistical analysis is displayed in Figure 2. GUD was extracted based on the NDPI calculated from the remote sensing data (MOD09A1) by the median method. Meteorological indicators were calculated from the temperature, precipitation, and insolation. A partial correlation analysis was used to investigate the relationship between GUD and $\mathrm{T}_{\max }, \mathrm{T}_{\min }$, and precipitation at the season or month scale. A sensitivity analysis was used to investigate the sensitivity of GUD to the meteorological indicators. 


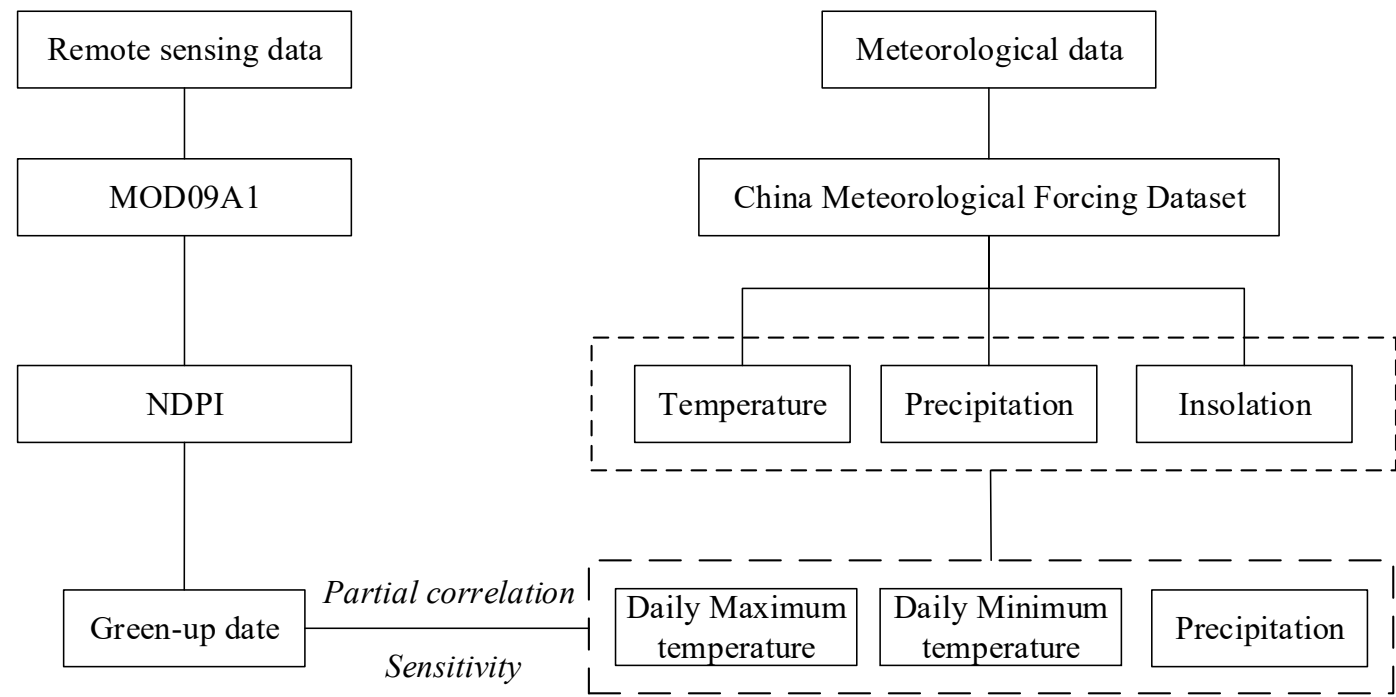

Meteorological indicators

Figure 2. Flow chart of the key indicator computations and statistical analysis.

\section{Results}

\subsection{Spatial and Temporal Patterns of GUD}

The multiyear mean remote sensing green-up dates (Figure 3) ranged from DOY (day of year) 90 in warm and dry areas to DOY 150 in cold and wet areas across the Hulun Buir grassland; the analysis also revealed spatial variations that were delayed from the west and east to the central region. The mean GUD across the whole area was DOY 113.1. The mean standard deviation across the whole area was 9.9 days. The temperate steppe had the earliest green-up date (DOY $104 \pm 8.2 ;$ mean \pm standard deviation), followed by the temperate meadow steppe (DOY $114 \pm 7.1$ ), lowland meadow (DOY $120 \pm 12.4$ ), and upland meadow (DOY $119 \pm 5.4$ ).

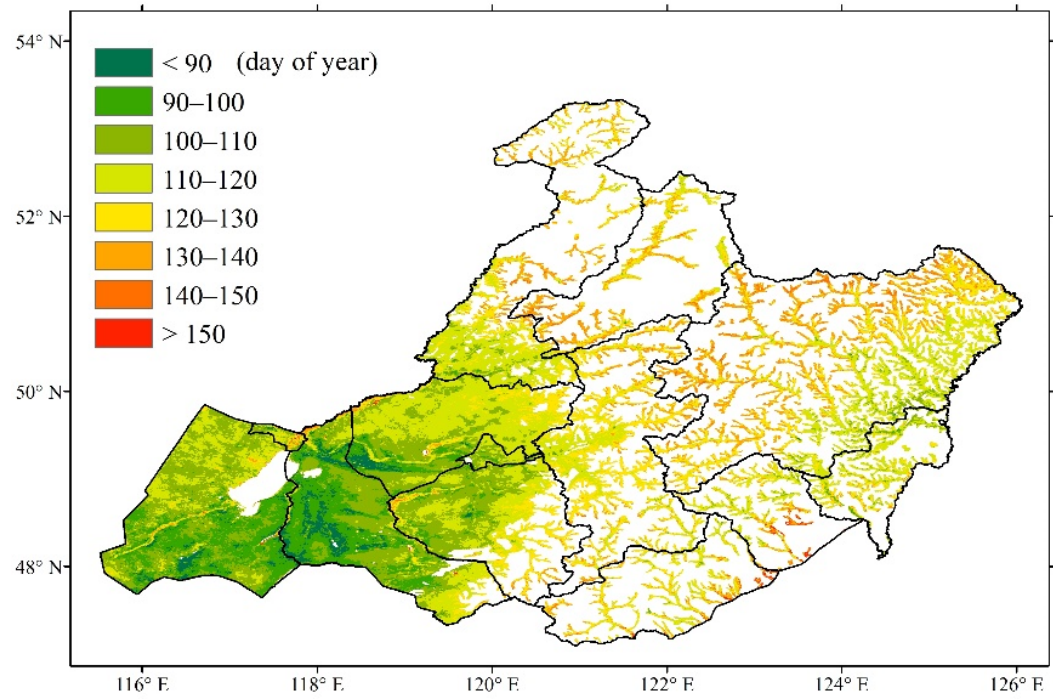

Figure 3. Mean GUD between 2001 and 2018.

The trends in green-up dates decreased from the west and east to the central region (Figure 4 ) and ranged from -20 days/decade to 20 days/decade. The mean trend overall was -3.1 days/decade. However, only $0.01 \%$ of the pixels exhibited significant $(p<0.05)$ positive changes, and where mainly distributed in the northwestern temperate steppe; $25.0 \%$ of pixels exhibited significant $(p<0.05)$ negative changes, and where mainly distributed in the temperate meadow steppe and northeast lowland meadow. The areas with 
large delayed trends were primarily concentrated in the temperate steppe, whereas the areas with large advanced trends were primarily concentrated in the lowland meadow areas.

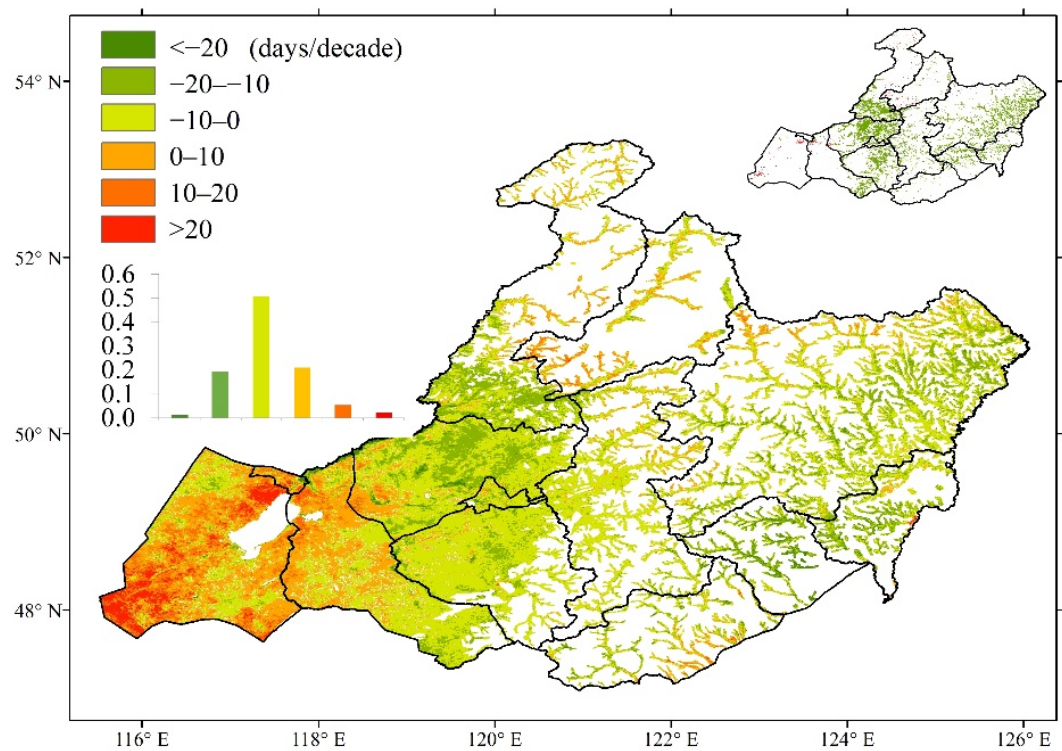

Figure 4. Spatial pattern of the temporal trends in green-up dates (in days per decade) between 2001 and 2018. The inset shown at the top-right of the figure indicates pixels with a significant $(p<0.05)$ increase (red) or decrease (green). The middle-left inset shows the frequency distribution of the trends corresponding to the values indicated by the map legend.

\subsection{Spatial and Temporal Patterns of Meteorological Indicators}

To further study the variation in air temperature, $T_{\max }$ and $T_{\min }$ were calculated, and the variation in air temperature in winter and spring was analyzed. The trend analysis was conducted using the winter temperatures from 2001 to 2018, and the results are shown in Figure 5. On the whole, the variation trend in $\mathrm{T}_{\max }$ and $\mathrm{T}_{\min }$ is consistent in most regions, and the area with a significant decreasing trend accounted for $0.4 \%$ pixels and $10.4 \%$ pixels of the area, respectively. The average trend in $\mathrm{T}_{\max } \mathrm{was}-0.46{ }^{\circ} \mathrm{C} / \mathrm{decade}$, while the average trend in $\mathrm{T}_{\min }$ was $-1.06^{\circ} \mathrm{C} /$ decade. The decline in $\mathrm{T}_{\min }$ was higher than that of $\mathrm{T}_{\text {max }}$.

The spring temperature variation trend is shown in Figure 6. The variation trends in $\mathrm{T}_{\max }$ and $\mathrm{T}_{\min }$ are not significant in most regions. $\mathrm{T}_{\max }$ mainly shows an increasing trend, accounting for $99.5 \%$ of the area, while $\mathrm{T}_{\min }$ also shows an increasing trend, accounting for $54.9 \%$ of the area. The area with a significant decreasing trend of $\mathrm{T}_{\min }$ accounted for $4.3 \%$ pixels and the area with a significant increasing trend of $\mathrm{T}_{\max }$ accounted for $2.8 \%$ pixels. The average trend in $\mathrm{T}_{\max }$ was $0.93{ }^{\circ} \mathrm{C} /$ decade, while the average trend of $\mathrm{T}_{\min }$ was $0.13^{\circ} \mathrm{C} /$ decade. In spring, the increase of $\mathrm{T}_{\max }$ was higher than that of $\mathrm{T}_{\min }$.

The winter precipitation variation trend is shown in Figure 7. From the perspective of the whole Hulun Buir grassland, there are many regions with small fluctuations in winter precipitation, with an average variation trend of $-1.9 \mathrm{~mm} /$ decade, and $2.6 \%$ pixels with a significant variation trend. Increasing trends accounted for $21.9 \%$ of the whole region, but no area with a significant variation trend. 

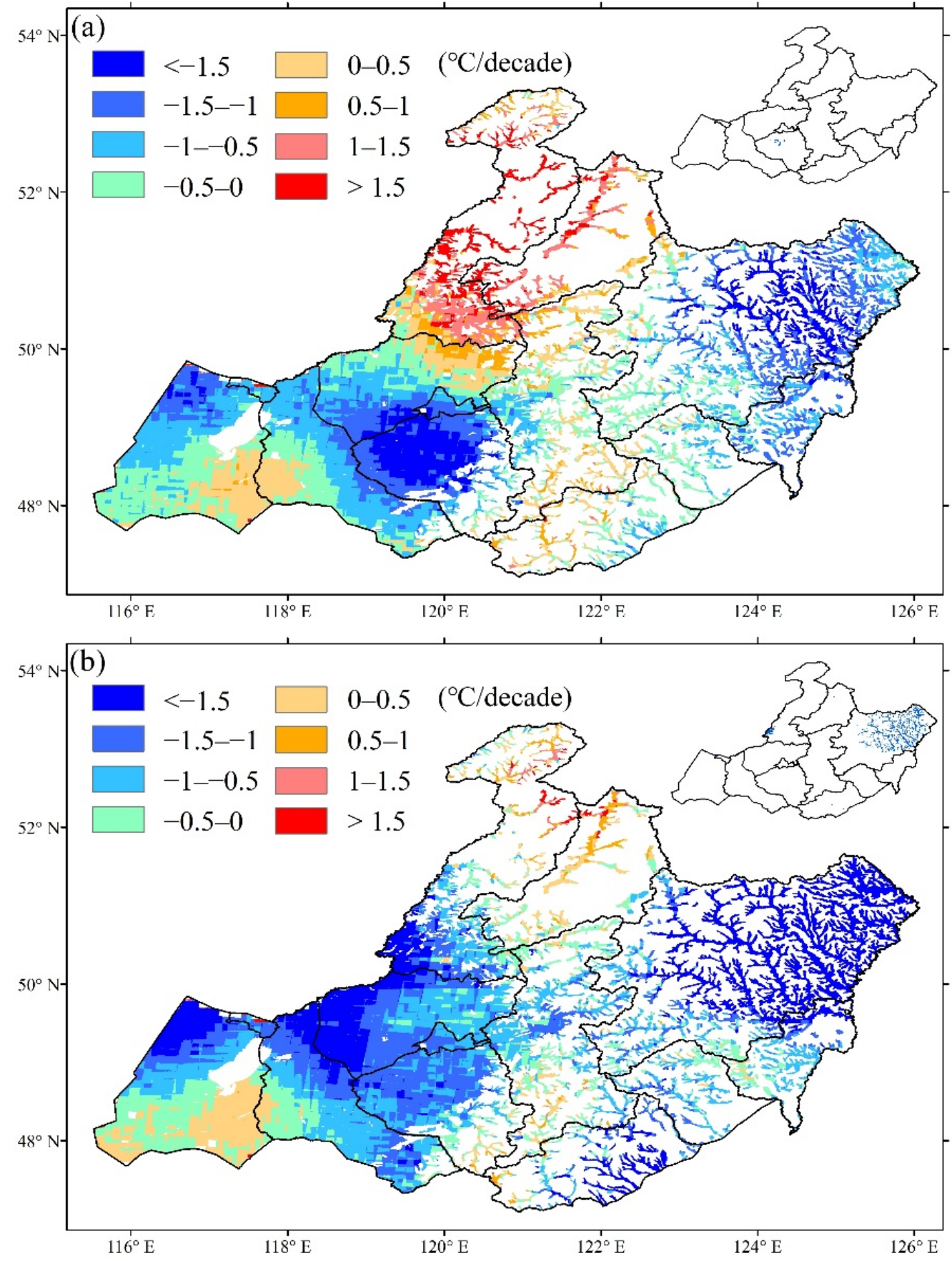

Figure 5. Spatial pattern of the temporal trends in winter daily maximum temperature (a) and winter daily minimum temperature (b) between 2001 and 2018. The top-right insets indicate pixels with a significant $(p<0.05)$ increase (red) or decrease (blue). 

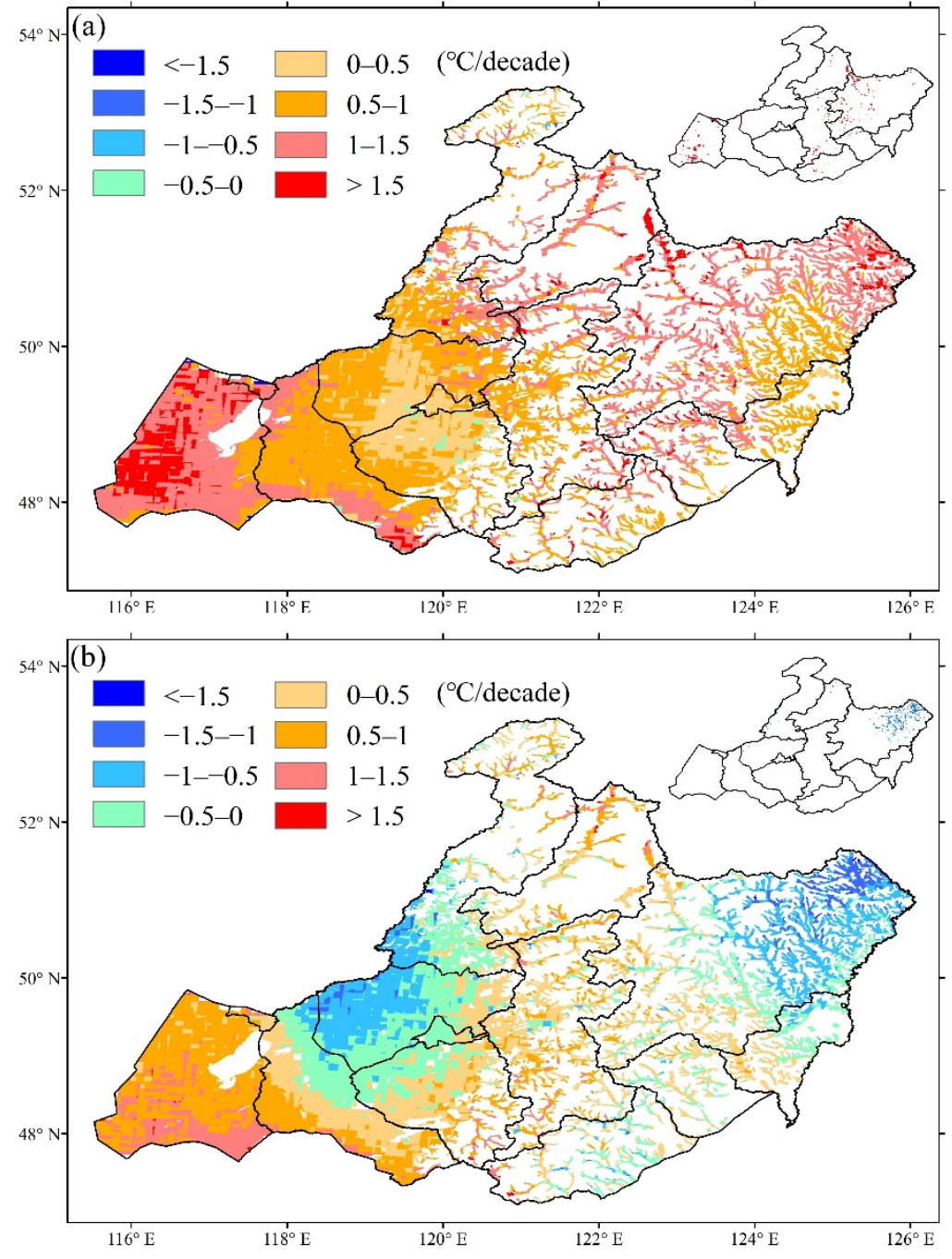

Figure 6. Spatial pattern of the temporal trends in spring daily maximum temperature (a) and spring daily minimum temperature (b) between 2001 and 2018. The top-right insets indicate pixels with a significant $(p<0.05)$ increase (red) or decrease (blue).

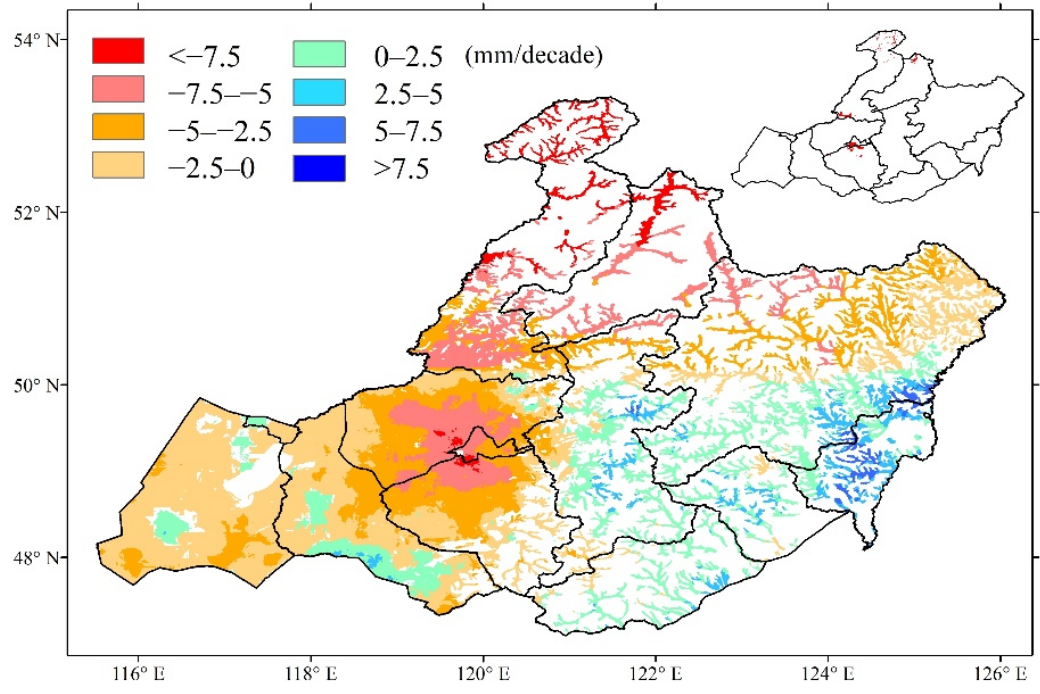

Figure 7. Spatial pattern of the temporal trends in total winter precipitation between 2001 and 2018. The top-right insets indicate pixels with a significant $(p<0.05)$ increase (blue) or decrease (red). 
The spring precipitation variation trend is shown in Figure 8. From the perspective of the whole study area, there were many regions with small fluctuations in spring precipitation, with an average trend of $-4.8 \mathrm{~mm} /$ decade, but only $0.5 \%$ pixels with a significant increase $(p<0.05)$. The increasing trend accounts for $26.3 \%$ area, and $61.5 \%$ have a trend in spring precipitation of $\pm 10 \mathrm{~mm} /$ decade, which has a small fluctuation range.

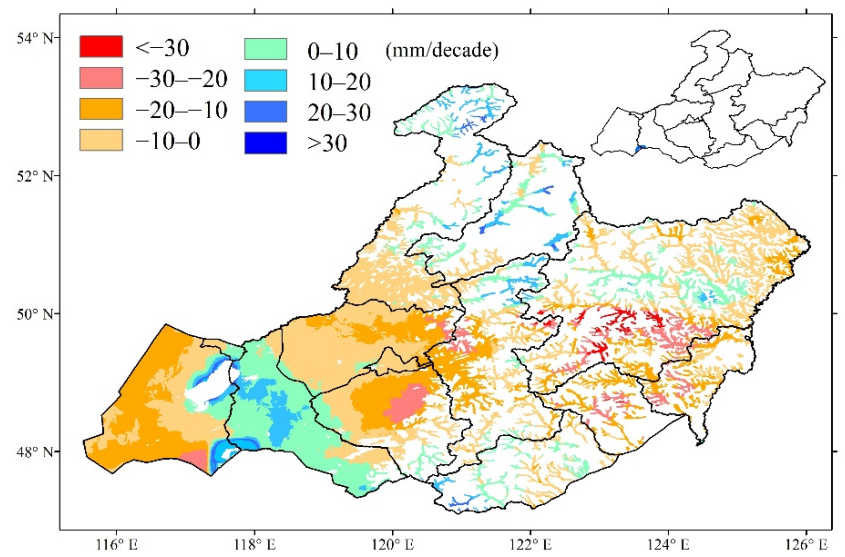

Figure 8. Spatial pattern of the temporal trends in total spring precipitation between 2001 and 2018. The top-right insets indicate pixels with a significant $(p<0.05)$ increase (blue) or decrease (red).

\subsection{Partial Correlation Analysis between Green-Up Date and Meteorological Indicators}

\subsubsection{Partial Correlation Analysis in Winter}

Partial correlation analysis was conducted for vegetation GUD to $T_{\max }, T_{\min }$, and precipitation in winter (Table 1 ). Across the entire region, $63.2 \%$ of pixels showed a negative partial correlation between GUD and $\mathrm{T}_{\max }$ in winter (Figure 9a), of which $13.7 \%$ of the pixel partial correlation coefficients were less than $-0.50(0.50$ corresponds to $p=0.05)$. Furthermore, only $3.3 \%$ of the pixel partial correlation coefficients were greater than 0.50 . In total, $57.6 \%$ of pixels showed a positive partial correlation between GUD and $\mathrm{T}_{\min }$ in winter (Figure $9 \mathrm{~b}$ ), of which $7.2 \%$ of the pixel partial correlation coefficients were greater than 0.50 . Only $1.6 \%$ of the pixel partial correlation coefficients were greater than 0.62 . Compared with $\mathrm{T}_{\max }$ and $\mathrm{T}_{\min }$, precipitation had less influence on GUD (Figure 9c). A total of $4.1 \%$ of the pixel partial correlation coefficients were greater than 0.50 .

Table 1. The pixels proportion of the partial correlation in winter (\%).

\begin{tabular}{|c|c|c|c|c|c|}
\hline \multicolumn{2}{|c|}{$\begin{array}{l}\text { Partial Correlation } \\
\text { in Winter }\end{array}$} & \multirow{2}{*}{$\begin{array}{c}\begin{array}{c}\text { Significant } \\
\text { Negative }(p<0.05)\end{array} \\
4.5\end{array}$} & \multirow{2}{*}{$\begin{array}{c}\begin{array}{c}\text { Significant } \\
\text { Positive }(p<\mathbf{0 . 0 5})\end{array} \\
4.6\end{array}$} & \multirow{2}{*}{$\begin{array}{c}\begin{array}{c}\text { Non-Significant } \\
\text { Negative }(p>\mathbf{0 . 0 5})\end{array} \\
49\end{array}$} & \multirow{2}{*}{$\begin{array}{c}\begin{array}{c}\text { Non-Significant } \\
\text { Positive }(p>0.05)\end{array} \\
41.9\end{array}$} \\
\hline \multirow{5}{*}{ GUD and $\mathrm{T}_{\max }$} & TS & & & & \\
\hline & TMS & 33.9 & 1.1 & 51.3 & 13.7 \\
\hline & UM & 46.6 & 0.3 & 40.7 & 12.4 \\
\hline & LM & 13.3 & 2.9 & 50.4 & 33.4 \\
\hline & study area & 13.7 & 3.3 & 49.5 & 33.5 \\
\hline \multirow{5}{*}{ GUD and $T_{\min }$} & TS & 3.5 & 1.5 & 51.4 & 43.6 \\
\hline & TMS & 0.9 & 13.8 & 28.6 & 56.7 \\
\hline & UM & 0.3 & 19.2 & 16 & 64.5 \\
\hline & LM & 2.3 & 9.2 & 35.1 & 53.4 \\
\hline & study area & 2.6 & 7.2 & 39.8 & 50.4 \\
\hline \multirow{5}{*}{$\begin{array}{l}\text { GUD and } \\
\text { precipitation }\end{array}$} & TS & 0.3 & 4.9 & 38.4 & 56.4 \\
\hline & TMS & 1.3 & 9.2 & 33.3 & 56.2 \\
\hline & UM & 1.7 & 2.4 & 29.4 & 66.5 \\
\hline & LM & 7 & 2.2 & 57.8 & 33 \\
\hline & study area & 3.6 & 4.1 & 46.3 & 46 \\
\hline
\end{tabular}



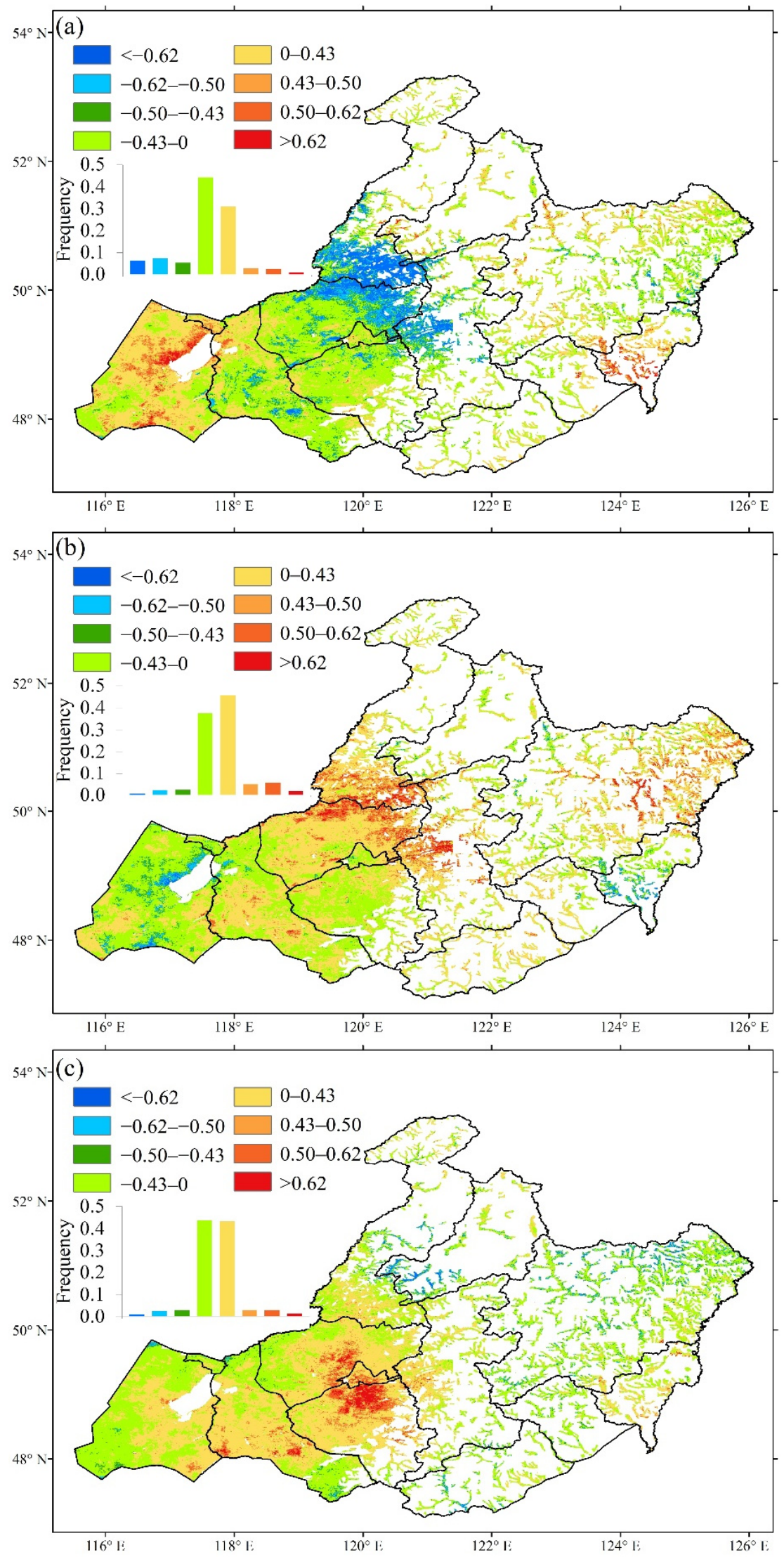

Figure 9. Spatial patterns of the interannual partial correlations between green-up date and daily maximum temperature (a), daily minimum temperature (b), and precipitation (c) in winter. Partial correlation coefficient values of $\pm 0.62, \pm 0.50$, and \pm 0.43 correspond to significance at $p=0.01$, $p=0.05$, and $p=0.10$, respectively. The middle-left insets show the frequency distributions of trends corresponding to the values indicated by the map legends. 
In TMS, UM, and LM, $\mathrm{T}_{\max }$ in winter was negatively correlated with GUD, and the significant correlation pixels proportions were $33.9 \%, 46.6 \%$, and $13.3 \%$, respectively. $\mathrm{T}_{\min }$ in winter was positively correlated with GUD, and the significant correlation pixels proportions were $13.8 \%, 19.2 \%$, and $9.2 \%$, respectively. In TS there was little correlation between temperature/precipitation and GUD.

\subsubsection{Partial Correlation Analysis in Spring}

Partial correlation analysis was conducted for vegetation GUD to $T_{\max }, T_{\min }$, and precipitation in spring (Table 2). Across the entire region, $61.3 \%$ of pixels showed a negative partial correlation between GUD and $\mathrm{T}_{\max }$ in spring (Figure 10a), of which $7.5 \%$ of the pixel partial correlation coefficients were less than -0.50 . Only $3.1 \%$ of the pixel partial correlation coefficients were greater than $0.50 ; 57.0 \%$ of pixels showed a negative partial correlation between GUD and $\mathrm{T}_{\min }$ in spring (Figure 10b), of which $4.2 \%$ of the pixel partial correlation coefficients were less than -0.50 . Only $2.1 \%$ of the pixel partial correlation coefficients were greater than $0.50 ; 59.0 \%$ of pixels showed a negative partial correlation between GUD and precipitation in spring (Figure 10c), of which $8.3 \%$ of the pixel partial correlation coefficients were less than -0.50 .

Table 2. The pixels proportion of the partial correlation in spring (\%).

\begin{tabular}{|c|c|c|c|c|c|}
\hline \multicolumn{2}{|c|}{$\begin{array}{c}\text { Partial Correlation } \\
\text { in Spring }\end{array}$} & \multirow{2}{*}{$\begin{array}{c}\begin{array}{c}\text { Significant } \\
\text { Negative }(\boldsymbol{p}<\mathbf{0 . 0 5})\end{array} \\
0.8\end{array}$} & \multirow{2}{*}{$\begin{array}{c}\begin{array}{c}\text { Significant } \\
\text { Positive }(p<0.05)\end{array} \\
3.4\end{array}$} & \multirow{2}{*}{$\begin{array}{c}\text { Non-Significant } \\
\text { Negative }(p>\mathbf{0 . 0 5}) \\
50\end{array}$} & \multirow{2}{*}{$\begin{array}{c}\begin{array}{c}\text { Non-Significant } \\
\text { Positive }(p>0.05)\end{array} \\
45.8\end{array}$} \\
\hline \multirow{5}{*}{ GUD and $T_{\max }$} & TS & & & & \\
\hline & TMS & 14 & 1.5 & 60.6 & 23.9 \\
\hline & UM & 26.2 & 0.9 & 53.7 & 19.2 \\
\hline & LM & 9.6 & 3 & 55.4 & 32 \\
\hline & study area & 7.5 & 3.1 & 53.7 & 35.7 \\
\hline \multirow{5}{*}{ GUD and $T_{\min }$} & TS & 5 & 0.6 & 61.9 & 32.5 \\
\hline & TMS & 5 & 0.5 & 60 & 34.5 \\
\hline & UM & 0.8 & 2.3 & 45.3 & 51.6 \\
\hline & LM & 3.1 & 3.7 & 44.5 & 48.7 \\
\hline & study area & 4.2 & 2.1 & 52.8 & 40.9 \\
\hline \multirow{5}{*}{$\begin{array}{c}\text { GUD and } \\
\text { precipitation }\end{array}$} & TS & 18.3 & 0.1 & 66.6 & 15 \\
\hline & TMS & 0.2 & 0.2 & 57.2 & 42.4 \\
\hline & UM & 0.3 & 1 & 59.7 & 39 \\
\hline & LM & 3.1 & 0.5 & 36.6 & 59.8 \\
\hline & study area & 8.3 & 0.3 & 50.7 & 40.7 \\
\hline
\end{tabular}

In TS, $18.3 \%$ of pixels showed a negative partial correlation between GUD and precipitation in spring. GUD in TS was mainly influenced by precipitation in spring. In TMS, UM, and LM, $\mathrm{T}_{\max }$ had a greater influence on GUD than $\mathrm{T}_{\min }$ and precipitation, and the pixels proportions of GUD and $\mathrm{T}_{\max }$ were $14 \%, 26.2 \%$, and $9.6 \%$, respectively.

Since the GUD happens in the spring, we suggest 1 month (March, April, or May) in spring is needed for a more fine-scale analysis. 

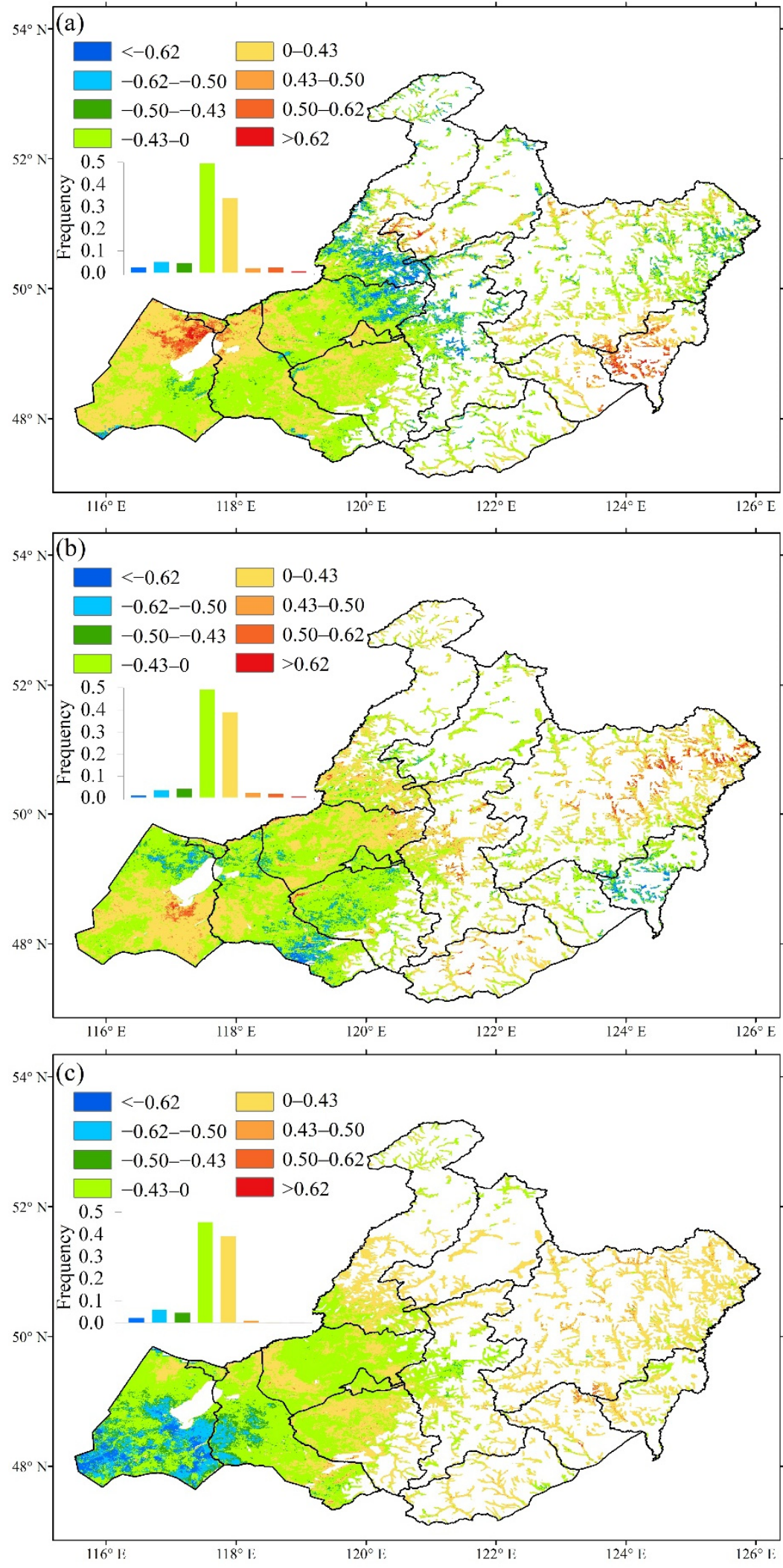

Figure 10. Spatial patterns of the interannual partial correlations between green-up date and daily maximum temperature (a), daily minimum temperature (b), and precipitation (c) in spring. Partial correlation coefficient values of $\pm 0.62, \pm 0.50$, and \pm 0.43 correspond to significance at $p=0.01$, $p=0.05$, and $p=0.10$, respectively. The middle-left insets show the frequency distributions of the trends corresponding to the values indicated by the map legends. 


\subsubsection{Partial Correlation Analysis in March}

Partial correlation analysis was conducted for vegetation GUD to $\mathrm{T}_{\max }, \mathrm{T}_{\min }$, and precipitation in May (Table 3). Across the entire region, $79.3 \%$ of pixels showed a positive partial correlation between GUD and $\mathrm{T}_{\max }$ in March (Figure 11a), of which $10.0 \%$ of the pixel partial correlation coefficients were greater than 0.50 . Only $1.9 \%$ of the pixel partial correlation coefficients were less than -0.50 . A total of $70.3 \%$ of pixels showed a negative partial correlation between GUD and $\mathrm{T}_{\min }$ in March (Figure $11 \mathrm{~b}$ ), of which $31.9 \%$ of the pixel partial correlation coefficients were less than -0.50 , and $2.5 \%$ of the pixel partial correlation coefficients were greater than 0.50 . The pixels $(59.3 \%)$ showed a positive partial correlation between GUD and precipitation in spring (Figure 11c), of which $4.4 \%$ of the pixel partial correlation coefficients were greater than 0.50 and $0.9 \%$ of the pixel partial correlation coefficients were less than -0.50 . Increasing $\mathrm{T}_{\min }$ in March can make vegetation greening faster, which was distributed in the central and Midwest region.

In TMS and UM, $\mathrm{T}_{\max }$ had a greater influence on GUD than that in TS and LM. The significant positive pixels proportion of GUD and $\mathrm{T}_{\max }$ were $25.3 \%$ and $26.2 \%$ in TMS and UM. In TS, TMS, UM, and LM, $\mathrm{T}_{\min }$ had a great influence on GUD, with significant positive pixels proportions of $27.3 \%, 73.95,65.9 \%$, and $22.1 \%$, respectively. Precipitation had influence only in UM, with a significant positive pixels proportion of $9.1 \%$.

Table 3. The pixels proportion of the partial correlation in March (\%).

\begin{tabular}{|c|c|c|c|c|c|}
\hline \multicolumn{2}{|c|}{$\begin{array}{l}\text { Partial Correlation } \\
\text { in March }\end{array}$} & \multirow{2}{*}{$\begin{array}{c}\begin{array}{c}\text { Significant } \\
\text { Negative }(p<0.05)\end{array} \\
3.2\end{array}$} & \multirow{2}{*}{$\begin{array}{c}\begin{array}{c}\text { Significant } \\
\text { Positive }(p<0.05)\end{array} \\
3.7\end{array}$} & \multirow{2}{*}{$\begin{array}{c}\begin{array}{c}\text { Non-Significant } \\
\text { Negative }(p>\mathbf{0 . 0 5})\end{array} \\
21.3\end{array}$} & \multirow{2}{*}{$\begin{array}{c}\begin{array}{c}\text { Non-Significant } \\
\text { Positive }(p>0.05)\end{array} \\
71.8\end{array}$} \\
\hline \multirow{5}{*}{ GUD and $T_{\max }$} & TS & & & & \\
\hline & TMS & 0.1 & 25.3 & 8 & 66.6 \\
\hline & UM & 0.3 & 33.1 & 4.3 & 62.3 \\
\hline & LM & 1.5 & 8.2 & 21.1 & 69.2 \\
\hline & study area & 1.9 & 10 & 18.9 & 69.2 \\
\hline \multirow{5}{*}{ GUD and $T_{\min }$} & TS & 27.3 & 3.1 & 41 & 28.6 \\
\hline & TMS & 73.9 & 0.3 & 20.8 & 5 \\
\hline & UM & 65.9 & 0.2 & 27.6 & 6.3 \\
\hline & LM & 22.1 & 2.9 & 41.2 & 33.9 \\
\hline & study area & 31.9 & 2.5 & 38.4 & 27.2 \\
\hline \multirow{5}{*}{$\begin{array}{l}\text { GUD and } \\
\text { precipitation }\end{array}$} & TS & 0.8 & 3.4 & 46.5 & 49.3 \\
\hline & TMS & 1.9 & 4.5 & 52.2 & 41.4 \\
\hline & UM & 1.1 & 9.1 & 28.5 & 61.3 \\
\hline & LM & 0.6 & 4.6 & 32.5 & 62.2 \\
\hline & study area & 0.9 & 4.4 & 39.8 & 54.9 \\
\hline
\end{tabular}



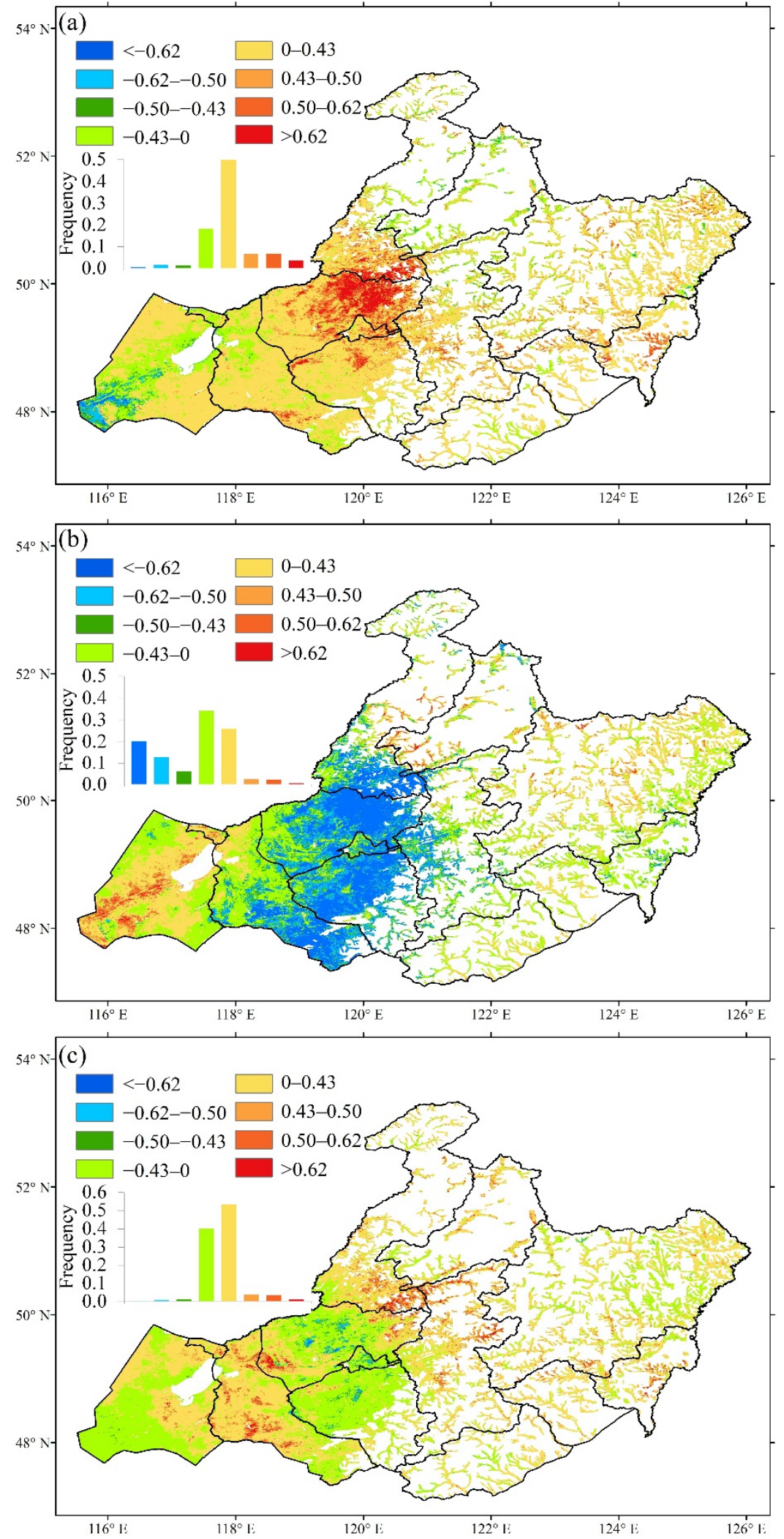

Figure 11. Spatial patterns of the interannual partial correlations between green-up date and daily maximum temperature (a), daily minimum temperature (b), and precipitation (c) in March. Partial correlation coefficient values of $\pm 0.62, \pm 0.50$, and \pm 0.43 correspond to significance at $p=0.01$, $p=0.05$, and $p=0.10$, respectively. The middle-left insets show the frequency distributions of the trends corresponding to the values indicated by the map legends. 


\subsubsection{Partial Correlation Analysis in April}

Partial correlation analysis was conducted for vegetation GUD to $\mathrm{T}_{\max }, \mathrm{T}_{\min }$, and precipitation in April (Table 4). There was mainly a negative correlation between GUD and the meteorological indicators in April. Across the entire region, $59.8 \%$ of pixels showed a negative partial correlation between GUD and $\mathrm{T}_{\max }$ in April (Figure 12a), of which $7.2 \%$ of the pixels partial correlation coefficients were less than -0.50 . A total of $3.0 \%$ of the pixels partial correlation coefficients were greater than 0.50 . The pixels $(60.7 \%)$ showed a negative partial correlation between GUD and $\mathrm{T}_{\min }$ in April (Figure 12b), of which 3.6\% of the pixel partial correlation coefficients were less than -0.50 , and less than $1 \%$ of the pixel partial correlation coefficients were greater than 0.50 . The pixels (58.6\%) showed a negative partial correlation between GUD and precipitation in April (Figure 12c), of which 9.4\% of the pixel partial correlation coefficients were less than -0.50 and less than $1 \%$ of the pixel partial correlation coefficients were greater than 0.50 .

In TS, $\mathrm{T}_{\max }$ and precipitation in April were negatively correlated with GUD, and the significant correlation area was $9.1 \%$ and $21.7 \%$, respectively. In TMS, there was little correlation between the meteorological indicators and GUD in April. For UM and LM, $\mathrm{T}_{\max }$ in April were negatively correlated with GUD, and the significant correlation area was $11.7 \%$ and $6.5 \%$. Precipitation had a greater influence on TS than that on TMS, UM, and LM. Vegetation in New Barag Right Banner and New Barag Left Banner, which are in semi-arid areas, mostly green-up in April. Precipitation in April can significantly advance GUD.

Table 4. The pixels proportion of the partial correlation in April (\%).

\begin{tabular}{|c|c|c|c|c|c|}
\hline \multicolumn{2}{|c|}{$\begin{array}{l}\text { Partial Correlation } \\
\text { in April }\end{array}$} & \multirow{2}{*}{$\begin{array}{c}\begin{array}{c}\text { Significant } \\
\text { Negative }(p<\mathbf{0 . 0 5})\end{array} \\
9.1\end{array}$} & \multirow{2}{*}{$\begin{array}{c}\begin{array}{c}\text { Significant } \\
\text { Positive }(p<0.05)\end{array} \\
3.7\end{array}$} & \multirow{2}{*}{$\begin{array}{c}\begin{array}{c}\text { Non-Significant } \\
\text { Negative }(p>\mathbf{0 . 0 5})\end{array} \\
50.4\end{array}$} & \multirow{2}{*}{$\begin{array}{c}\begin{array}{c}\text { Non-Significant } \\
\text { Positive }(p>0.05)\end{array} \\
36.8\end{array}$} \\
\hline \multirow{5}{*}{ GUD and $T_{\max }$} & TS & & & & \\
\hline & TMS & 4.1 & 0.8 & 68.1 & 27 \\
\hline & UM & 11.7 & 0.8 & 65.4 & 22 \\
\hline & LM & 6.5 & 3 & 50 & 40.5 \\
\hline & study area & 7.2 & 3 & 52.6 & 37.2 \\
\hline \multirow{5}{*}{ GUD and $T_{\min }$} & TS & 3.5 & 1.2 & 53 & 42.3 \\
\hline & TMS & 1.6 & 0.1 & 59.8 & 38.5 \\
\hline & UM & 1.5 & 0.3 & 59.4 & 38.8 \\
\hline & LM & 3.9 & 0.6 & 59.1 & 36.4 \\
\hline & study area & 3.6 & 0.7 & 57.1 & 38.6 \\
\hline \multirow{5}{*}{$\begin{array}{l}\text { GUD and } \\
\text { precipitation }\end{array}$} & TS & 21.7 & 0.8 & 61.9 & 15.6 \\
\hline & TMS & 2.1 & 0.7 & 49.3 & 47.9 \\
\hline & UM & 0.2 & 1.6 & 35.7 & 62.4 \\
\hline & LM & 3.3 & 2.3 & 41.6 & 52.8 \\
\hline & study area & 0.4 & 1.7 & 49.2 & 39.7 \\
\hline
\end{tabular}



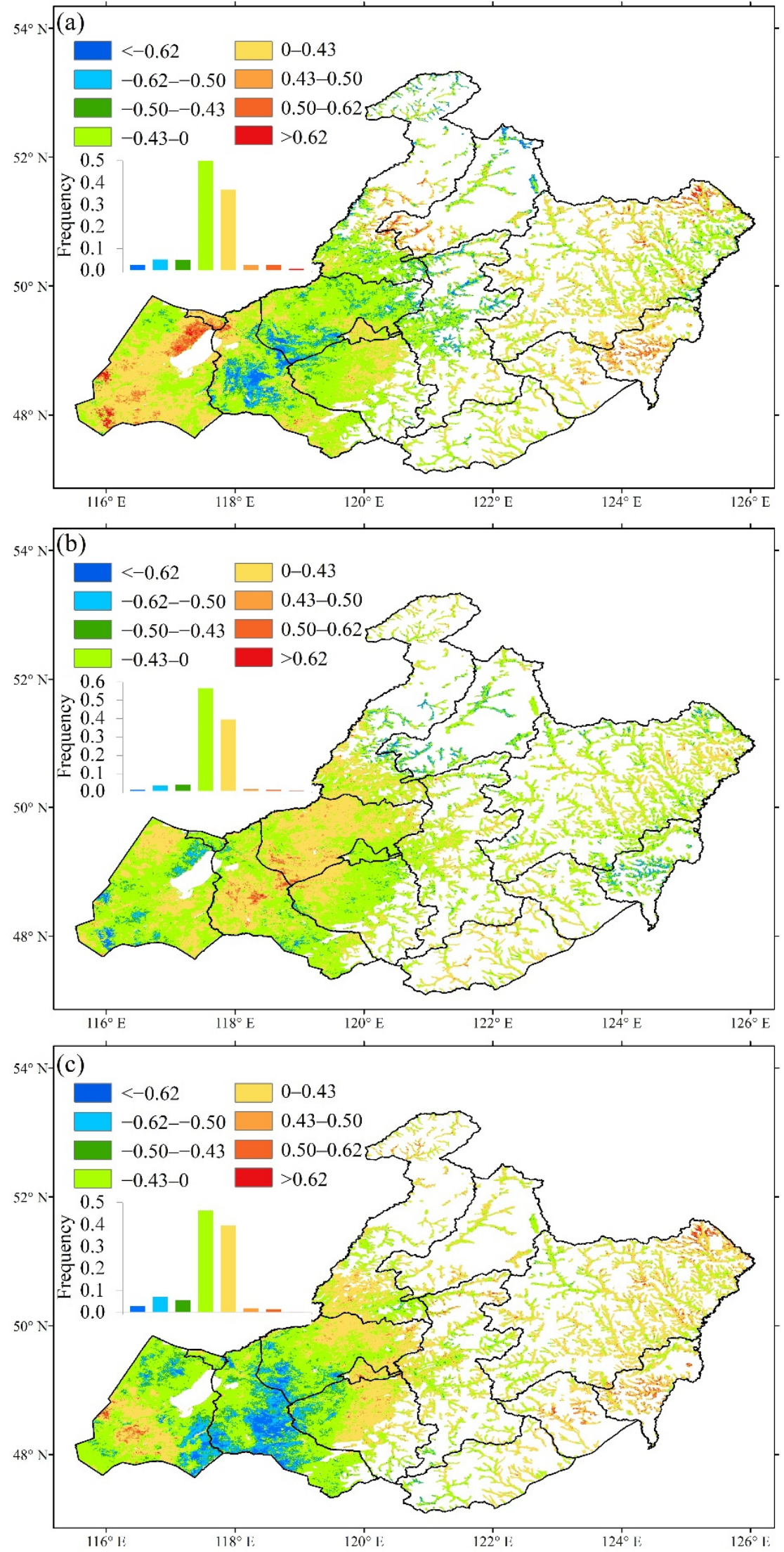

Figure 12. Spatial patterns of the interannual partial correlations between green-up date and daily maximum temperature (a), daily minimum temperature (b), and precipitation (c) in April. Partial correlation coefficient values of $\pm 0.62, \pm 0.50$, and \pm 0.43 correspond to significance at $p=0.01$, $p=0.05$, and $p=0.10$, respectively. The middle-left insets show the frequency distributions of trends corresponding to the values indicated by the map legends. 


\subsubsection{Partial Correlation Analysis in May}

Partial correlation analysis was conducted for vegetation GUD to $\mathrm{T}_{\max }, \mathrm{T}_{\min }$, and precipitation in May (Table 5). Across the entire region, $78.5 \%$ of pixels showed a negative partial correlation between GUD and $\mathrm{T}_{\max }$ in May (Figure 13a), of which $12.3 \%$ of the pixel partial correlation coefficients were less than -0.50 . Less than $1.0 \%$ of the pixel partial correlation coefficients were greater than 0.50 . The pixels $(89.8 \%)$ showed a positive partial correlation between GUD and $\mathrm{T}_{\min }$ in May (Figure 13b), of which $17.1 \%$ of the pixel partial correlation coefficients were greater than 0.50 and less than $1 \%$ of the pixel partial correlation coefficients were less than -0.50 . The pixels $(66.5 \%)$ showed a negative partial correlation between GUD and precipitation in May (Figure 13c), of which $8.6 \%$ of the pixel partial correlation coefficients were less than -0.50 and $0.4 \%$ of the pixel partial correlation coefficients were greater than 0.50 .

In TMS, UM, and $\mathrm{LM}, \mathrm{T}_{\max }$ and $\mathrm{T}_{\min }$ had the opposite effect to GUD. The pixels proportion of the partial correlation between GUD and $T_{\min }$ was slightly more than that between GUD and $T_{\max }$. The increased $T_{\min }$ can delay vegetation GUD in all types while the increased $\mathrm{T}_{\max }$ can advance vegetation GUD. Precipitation had an influence on GUD only in TS, and the significant negative correlation pixels proportion was $19.4 \%$.

Table 5. The pixels proportion of the partial correlation in May (\%).

\begin{tabular}{|c|c|c|c|c|c|}
\hline \multicolumn{2}{|c|}{$\begin{array}{l}\text { Partial Correlation } \\
\text { in May }\end{array}$} & \multirow{2}{*}{$\begin{array}{c}\begin{array}{c}\text { Significant } \\
\text { Negative }(p<0.05)\end{array} \\
11.1\end{array}$} & \multirow{2}{*}{$\begin{array}{c}\begin{array}{c}\text { Significant } \\
\text { Positive }(\boldsymbol{p}<\mathbf{0 . 0 5})\end{array} \\
0.3\end{array}$} & \multirow{2}{*}{$\begin{array}{c}\begin{array}{c}\text { Non-Significant } \\
\text { Negative }(p>\mathbf{0 . 0 5})\end{array} \\
77.6\end{array}$} & \multirow{2}{*}{$\begin{array}{c}\begin{array}{c}\text { Non-Significant } \\
\text { Positive }(p>0.05)\end{array} \\
11\end{array}$} \\
\hline \multirow{5}{*}{ GUD and $T_{\max }$} & TS & & & & \\
\hline & TMS & 22.3 & 0.1 & 70.1 & 7.5 \\
\hline & UM & 44.5 & 0 & 44.4 & 11.1 \\
\hline & LM & 8.2 & 0.1 & 59.6 & 32.2 \\
\hline & study area & 12.3 & 0.2 & 66.2 & 21.3 \\
\hline \multirow{5}{*}{ GUD and $T_{\min }$} & TS & 0.2 & 9.3 & 16.2 & 74.3 \\
\hline & TMS & 0.1 & 32.7 & 5.5 & 61.7 \\
\hline & UM & 0 & 51.8 & 1.7 & 46.5 \\
\hline & LM & 0 & 16.2 & 75.8 & 16.2 \\
\hline & study area & 0.1 & 17.1 & 10.2 & 72.6 \\
\hline \multirow{5}{*}{$\begin{array}{l}\text { GUD and } \\
\text { precipitation }\end{array}$} & TS & 19.4 & 0.1 & 57.9 & 22.6 \\
\hline & TMS & 0.6 & 0.2 & 84 & 15.2 \\
\hline & UM & 2.2 & 0.2 & 77.1 & 20.5 \\
\hline & LM & 3.6 & 0.7 & 51.1 & 44.5 \\
\hline & study area & 8.6 & 0.4 & 57.9 & 33.1 \\
\hline
\end{tabular}



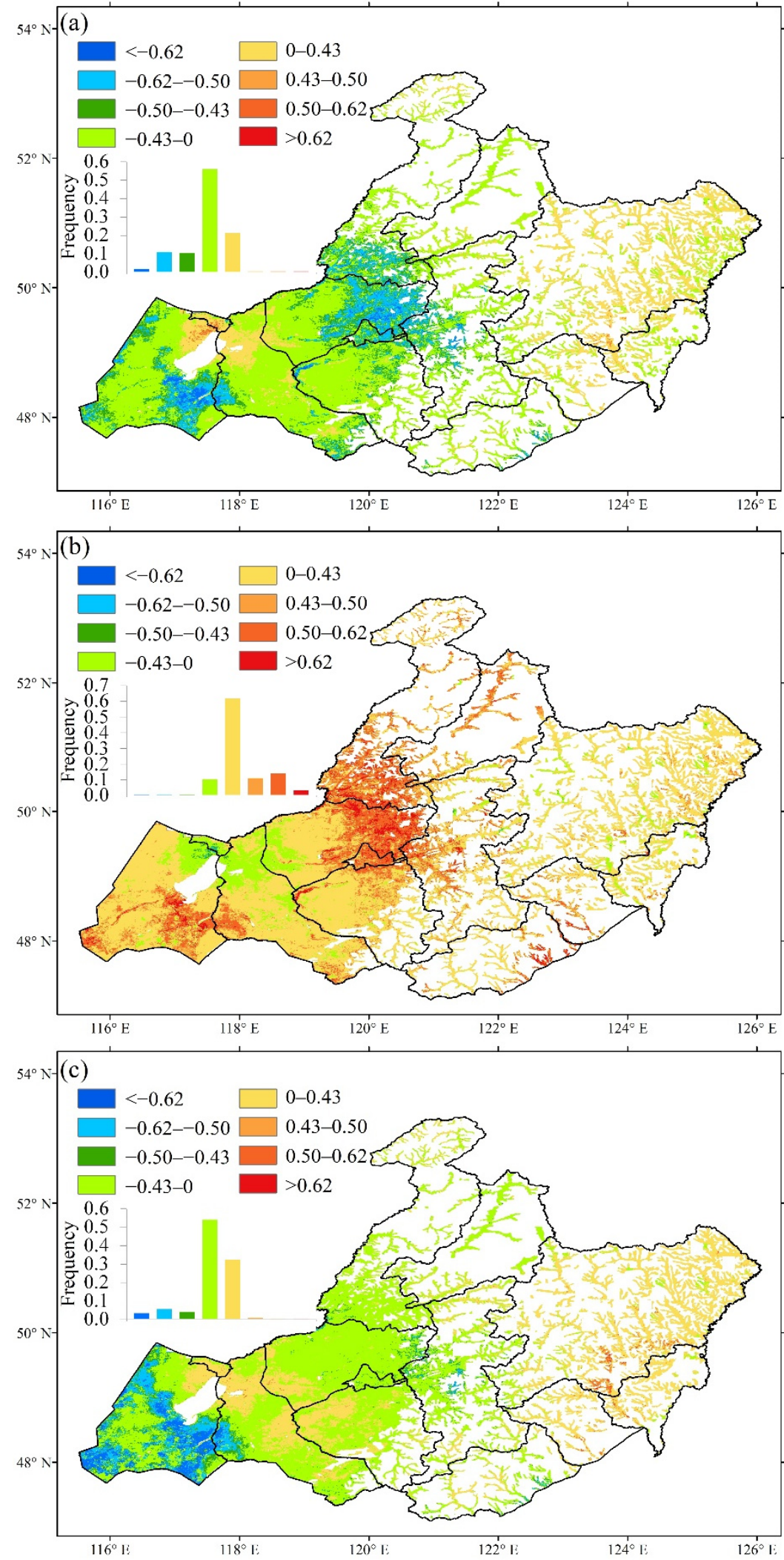

Figure 13. Spatial patterns of the interannual partial correlations between green-up date and daily maximum temperature (a), daily minimum temperature (b), and precipitation (c) in May. Partial correlation coefficient values of $\pm 0.62, \pm 0.50$, and \pm 0.43 correspond to significance at $p=0.01$, $p=0.05$, and $p=0.10$, respectively. The middle-left insets show the frequency distributions of trends corresponding to the values indicated by the map legends. 


\subsection{Sensitivity Analysis of Green-Up Date to Meteorological Indicators}

We calculated the average sensitivity of the significant positive and significant negative correlations between the GUD and meteorological indicators. We only pay attention to the areas where the proportion of significant partial pixels is more than $5 \%$ for sensitivity average calculation, which is marked in bold font in the tables.

\subsubsection{Sensitivity Analysis of TS}

Sensitivity analysis was conducted for vegetation GUD of TS to $T_{\max }, T_{\min }$, and precipitation in winter and spring (Table 6). In the TS region, $\mathrm{T}_{\max }, \mathrm{T}_{\min }$, and precipitation in winter have little influence on GUD, while $T_{\min }$ and precipitation in spring have great influence. In spring, the sensitivity of GUD to $\mathrm{T}_{\min }$ was -0.06 days $/{ }^{\circ} \mathrm{C}(\mathrm{GUD}$ advanced 0.06 days when temperature increase $1{ }^{\circ} \mathrm{C}$ ), and the sensitivity of GUD to precipitation was -0.41 days $/ \mathrm{mm}$ (GUD advanced 0.41 days when precipitation increase $1 \mathrm{~mm}$ ), mainly distributed across the area with the highest temperature and lowest precipitation. The GUD of this area was the earliest GUD in the study area.

Table 6. Sensitivity of the GUD to meteorological indicators of TS in winter and spring.

\begin{tabular}{cccc}
\hline $\begin{array}{c}\text { Sensitivity of GUD to } \\
\text { Meteorological Indicators } \mathbf{1}^{*}\end{array}$ & $\begin{array}{c}\text { Significant Negative } \\
(\boldsymbol{p}<\mathbf{0 . 0 5})\end{array}$ & $\begin{array}{c}\text { Significant Positive } \\
(\boldsymbol{p}<\mathbf{0 . 0 5})\end{array}$ \\
\hline \multirow{3}{*}{ winter } & GUD to $\mathrm{T}_{\max }$ & -0.09 & 0.02 \\
& GUD to $\mathrm{T}_{\min }$ & -0.01 & 0.00 \\
& GUD to precipitation & -0.11 & 0.36 \\
\hline \multirow{3}{*}{ spring } & GUD to $\mathrm{T}_{\max }$ & -0.07 & 0.02 \\
& GUD to T & 0.02 \\
& GUD to precipitation & $\mathbf{- 0 . 0 6}$ & 0.51 \\
\hline
\end{tabular}

${ }^{1}$ The unit is days $/{ }^{\circ} \mathrm{C}$ (sensitivity of GUD to $\mathrm{T}_{\max }$ or $\mathrm{T}_{\min }$ ) or days $/ \mathrm{mm}$ (sensitivity of GUD to precipitation).

Sensitivity analysis was conducted for vegetation GUD of TS to $T_{\max }, T_{\min }$, and precipitation in March, April, and May (Table 7). In the TS region, $\mathrm{T}_{\min }$ in March had the greatest influence on GUD. The sensitivity of GUD to $\mathrm{T}_{\min }$ in March was -0.17 days $/{ }^{\circ} \mathrm{C}$ while this temperature sensitivity was also largest. Precipitation in both April and May had a great influence on GUD. The sensitivity of GUD to precipitation in April was -0.32 days $/ \mathrm{mm}$, which is greater than the sensitivity in May.

Table 7. Sensitivity of GUD to meteorological indicators of TS in March, April and May.

\begin{tabular}{cccc}
\hline $\begin{array}{c}\text { Sensitivity of GUD to } \\
\text { Meteorological Indicators }\end{array}$ & $\begin{array}{c}\text { Significant Negative } \\
(\boldsymbol{p}<\mathbf{0 . 0 5 )}\end{array}$ & $\begin{array}{c}\text { Significant Positive } \\
(\boldsymbol{p}<\mathbf{0 . 0 5})\end{array}$ \\
\hline \multirow{3}{*}{ March } & GUD to $\mathrm{T}_{\max }$ & -0.09 & 0.01 \\
& GUD to $\mathrm{T}_{\min }$ & $\mathbf{- 0 . 1 7}$ & 0.03 \\
& GUD to precipitation & -0.07 & 0.20 \\
\hline \multirow{3}{*}{ April } & GUD to $\mathrm{T}_{\max }$ & $\mathbf{- 0 . 0 9}$ & 0.02 \\
& GUD to $\mathrm{T}_{\min }$ & -0.02 & 0.00 \\
& GUD to precipitation & $\mathbf{- 0 . 3 2}$ & 0.11 \\
\hline \multirow{2}{*}{ May } & GUD to $\mathrm{T}_{\max }$ & $\mathbf{- 0 . 0 1}$ & 0.01 \\
& GUD to $\mathrm{T}_{\min }$ & $\mathbf{- 0 . 0 1}$ & $\mathbf{0 . 0 2}$ \\
& GUD to precipitation & $\mathbf{- 0 . 1 7}$ & 0.18 \\
\hline
\end{tabular}

${ }^{1}$ The unit is days $/{ }^{\circ} \mathrm{C}$ (sensitivity of GUD to $\mathrm{T}_{\max }$ or $\mathrm{T}_{\min }$ ) or days $/ \mathrm{mm}$ (sensitivity of GUD to precipitation).

\subsubsection{Sensitivity Analysis of TMS}

Sensitivity analysis was conducted for vegetation GUD of TMS to $T_{\max }, T_{\min }$, and precipitation in winter and spring (Table 8 ). Whether in winter or in spring, $\mathrm{T}_{\max }$ have great influence in the northern TMS region, and the sensitivity of GUD to $\mathrm{T}_{\max }$ was -0.11 days $/{ }^{\circ} \mathrm{C}$ and -0.12 days $/{ }^{\circ} \mathrm{C}$, respectively. Compared with the $\mathrm{T}_{\max }, \mathrm{T}_{\min }$ has less 
influence and the sensitivity of GUD to $T_{\min }$ was far less than the sensitivity of GUD to $\mathrm{T}_{\max }$. Precipitation in winter and spring have little influence on GUD.

Table 8. Sensitivity of the GUD to meteorological indicators of TMS in winter and spring.

\begin{tabular}{cccc}
\hline $\begin{array}{c}\text { Sensitivity of GUD to } \\
\text { Meteorological Indicators }\end{array}$ & $\begin{array}{c}\text { Significant Negative } \\
(\boldsymbol{p}<\mathbf{0 . 0 5})\end{array}$ & $\begin{array}{c}\text { Significant Positive } \\
(\boldsymbol{p}<\mathbf{0 . 0 5})\end{array}$ \\
\hline \multirow{3}{*}{ Winter } & GUD to $\mathrm{T}_{\max }$ & $-\mathbf{0 . 1 1}$ & 0.04 \\
& GUD to $\mathrm{T}_{\min }$ & -0.01 & $\mathbf{0 . 0 0}$ \\
& GUD to precipitation & -0.28 & 0.35 \\
\hline \multirow{3}{*}{ Spring } & GUD to $\mathrm{T}_{\max }$ & $\mathbf{- 0 . 1 2}$ & 0.02 \\
& GUD to $\mathrm{T}_{\min }$ & -0.08 & $\mathbf{- 0 . 0 2}$ \\
& GUD to precipitation & -0.11 & 0.72 \\
\hline
\end{tabular}

${ }^{1}$ The unit is days $/{ }^{\circ} \mathrm{C}$ (sensitivity of GUD to $\mathrm{T}_{\max }$ or $\mathrm{T}_{\min }$ ) or days $/ \mathrm{mm}$ (sensitivity of GUD to precipitation).

Sensitivity analysis was conducted for vegetation GUD of TMS to $T_{\max }, T_{\min }$, and precipitation in March, April, and May (Table 9). In the TMS region, except in April, $\mathrm{T}_{\max }$ or $T_{\min }$ in March and May had influence on GUD. $T_{\min }$ in March had greatest influence on GUD. The sensitivity of GUD to $\mathrm{T}_{\min }$ in March was -0.15 days $/{ }^{\circ} \mathrm{C}$ while this temperature sensitivity was also the largest. The sensitivity of GUD to $\mathrm{T}_{\min }$ in May was 0.03 days $/{ }^{\circ} \mathrm{C}$ (GUD delayed 0.03 days when temperature increase $1{ }^{\circ} \mathrm{C}$ ), which had the opposite impact on GUD. Precipitation had little influence on GUD.

Table 9. Sensitivity of the GUD to meteorological indicators of TMS in March, April, and May.

\begin{tabular}{cccc}
\hline $\begin{array}{c}\text { Sensitivity of GUD to } \\
\text { Meteorological Indicators }\end{array}$ & $\begin{array}{c}\text { Significant Negative } \\
(\boldsymbol{p}<\mathbf{0 . 0 5})\end{array}$ & $\begin{array}{c}\text { Significant Positive } \\
(\boldsymbol{p}<\mathbf{0 . 0 5})\end{array}$ \\
\hline \multirow{3}{*}{ March } & GUD to $\mathrm{T}_{\max }$ & -0.37 & $-\mathbf{0 . 0 3}$ \\
& GUD to $\mathrm{T}_{\min }$ & $-\mathbf{0 . 1 5}$ & 0.09 \\
& GUD to precipitation & -0.04 & 0.30 \\
\hline \multirow{3}{*}{ April } & GUD to $\mathrm{T}_{\max }$ & -0.18 & 0.02 \\
& GUD to $\mathrm{T}_{\min }$ & -0.07 & -0.02 \\
& GUD to precipitation & -0.24 & 0.66 \\
\hline \multirow{2}{*}{ May } & GUD to $\mathrm{T}_{\max }$ & $-\mathbf{0 . 0 1}$ & 0.01 \\
& GUD to T & $\mathbf{0 . 0 3}$ \\
& GUD to precipitation & -0.01 & -0.10 \\
\hline
\end{tabular}

${ }^{1}$ The unit is days $/{ }^{\circ} \mathrm{C}$ (sensitivity of GUD to $\mathrm{T}_{\max }$ or $\mathrm{T}_{\min }$ ) or days $/ \mathrm{mm}$ (sensitivity of GUD to precipitation).

\subsubsection{Sensitivity Analysis of UM}

Sensitivity analysis was conducted for vegetation GUD of UM to $T_{\max }, T_{\min }$, and precipitation in winter and spring (Table 10). Similar to TMS, whether in winter or in spring, $\mathrm{T}_{\max }$ have great influence in UM region, and the sensitivity of GUD to $\mathrm{T}_{\max }$ was -0.10 days $/{ }^{\circ} \mathrm{C}$ and -0.14 days $/{ }^{\circ} \mathrm{C}$, respectively. Compared with the $\mathrm{T}_{\max }, \mathrm{T}_{\min }$ has less influence and the sensitivity of GUD to $\mathrm{T}_{\min }$ was far less than the sensitivity of GUD to $\mathrm{T}_{\text {max. Precipitation in winter and spring have little influence on GUD. }}$

Sensitivity analysis was conducted for vegetation GUD of UM to $T_{\max }, T_{\min }$, and precipitation in March, April, and May (Table 11). In the UM region, except for $\mathrm{T}_{\min }$ in April, $\mathrm{T}_{\max }$ or $\mathrm{T}_{\min }$ in March, April and May had an influence on the GUD. $\mathrm{T}_{\min }$ had much more influence on GUD in March and May. In March, the sensitivity of GUD to $\mathrm{T}_{\min }\left(-0.13\right.$ days $\left./{ }^{\circ} \mathrm{C}\right)$ was far more than the sensitivity of GUD to $\mathrm{T}_{\max }\left(0.02\right.$ days $\left./{ }^{\circ} \mathrm{C}\right)$. However, in May, the sensitivity of GUD to $\mathrm{T}_{\min }\left(-0.02\right.$ days $\left./{ }^{\circ} \mathrm{C}\right)$ was nearly the same as the sensitivity of GUD to $\mathrm{T}_{\max }\left(0.02\right.$ days $\left./{ }^{\circ} \mathrm{C}\right)$. Precipitation has less influence on GUD than temperature. In this grassland type, the sensitivity of GUD in March was the greatest one. 
Table 10. Sensitivity of the GUD to meteorological indicators of UM in winter and spring.

\begin{tabular}{cccc}
\hline $\begin{array}{c}\text { Sensitivity of GUD to } \\
\text { Meteorological Indicators }\end{array}$ & $\begin{array}{c}\text { Significant Negative } \\
(\boldsymbol{p}<\mathbf{0 . 0 5})\end{array}$ & $\begin{array}{c}\text { Significant Positive } \\
(\boldsymbol{p}<\mathbf{0 . 0 5})\end{array}$ \\
\hline \multirow{3}{*}{ winter } & GUD to $\mathrm{T}_{\max }$ & $\mathbf{- 0 . 1 0}$ & 0.03 \\
& GUD to $\mathrm{T}_{\min }$ & -0.04 & $\mathbf{0 . 0 0}$ \\
& GUD to precipitation & -0.34 & 0.39 \\
\hline \multirow{3}{*}{ spring } & GUD to $\mathrm{T}_{\max }$ & $\mathbf{- 0 . 1 4}$ & 0.03 \\
& GUD to $\mathrm{T}_{\min }$ & -0.04 & 0.00 \\
& GUD to precipitation & - & 1.00 \\
\hline
\end{tabular}

${ }^{1}$ The unit is days $/{ }^{\circ} \mathrm{C}$ (sensitivity of GUD to $\mathrm{T}_{\max }$ or $\mathrm{T}_{\min }$ ) or days $/ \mathrm{mm}$ (sensitivity of GUD to precipitation)

Table 11. Sensitivity of the GUD to meteorological indicators of UM in March, April, and May.

\begin{tabular}{cccc}
\hline $\begin{array}{c}\text { Sensitivity of GUD to } \\
\text { Meteorological Indicators }\end{array}$ & $\begin{array}{c}\text { Significant Negative } \\
(\boldsymbol{p}<\mathbf{0 . 0 5})\end{array}$ & $\begin{array}{c}\text { Significant Positive } \\
(\boldsymbol{p}<\mathbf{0 . 0 5})\end{array}$ \\
\hline \multirow{3}{*}{ March } & GUD to $\mathrm{T}_{\max }$ & -0.21 & $\mathbf{0 . 0 2}$ \\
& GUD to $\mathrm{T}_{\min }$ & $-\mathbf{0 . 1 3}$ & 0.10 \\
& GUD to precipitation & -0.05 & $\mathbf{0 . 3 5}$ \\
\hline \multirow{3}{*}{ April } & GUD to $\mathrm{T}_{\max }$ & $\mathbf{- 0 . 2 2}$ & 0.02 \\
& GUD to $\mathrm{T}_{\min }$ & -0.04 & 0.01 \\
& GUD to precipitation & -0.17 & 1.03 \\
\hline \multirow{2}{*}{ May } & GUD to $\mathrm{T}_{\max }$ & $\mathbf{- 0 . 0 2}$ & 0.02 \\
& GUD to $\mathrm{T}_{\min }$ & - & $\mathbf{0 . 0 3}$ \\
& GUD to precipitation & -0.02 & 0.36
\end{tabular}

${ }^{1}$ The unit is days $/{ }^{\circ} \mathrm{C}$ (Sensitivity of GUD to $\mathrm{T}_{\max }$ or $\mathrm{T}_{\min }$ ) or days $/ \mathrm{mm}$ (Sensitivity of GUD to precipitation).

\subsubsection{Sensitivity Analysis of LM}

Sensitivity analysis was conducted for vegetation GUD of LM to $T_{\max }, T_{\min }$, and precipitation in winter and spring (Table 12). Similar to TMS and UM, whether in winter or in spring, $\mathrm{T}_{\max }$ have a great influence on the UM region, and the sensitivity of GUD to $\mathrm{T}_{\max }$ was -0.09 days $/{ }^{\circ} \mathrm{C}$ and -0.10 days $/{ }^{\circ} \mathrm{C}$, respectively. Compared with the $\mathrm{T}_{\max }, \mathrm{T}_{\min }$ have less influence in winter and the sensitivity of GUD to $\mathrm{T}_{\min }$ was 0.04 days $/{ }^{\circ} \mathrm{C}$ (GUD delayed 0.04 days when temperature increase $1^{\circ} \mathrm{C}$ ). Precipitation in spring have a great influence on GUD, and the sensitivity of GUD to precipitation was -0.20 days $/ \mathrm{mm}$, which was mainly distributed in the southwestern study area.

Table 12. Sensitivity of the GUD to meteorological indicators of LM in winter and spring.

\begin{tabular}{cccc}
\hline $\begin{array}{c}\text { Sensitivity of GUD to } \\
\text { Meteorological Indicators }\end{array}$ & $\begin{array}{c}\text { Significant Negative } \\
(\boldsymbol{p}<\mathbf{0 . 0 5})\end{array}$ & $\begin{array}{c}\text { Significant Positive } \\
(\boldsymbol{p}<\mathbf{0 . 0 5})\end{array}$ \\
\hline \multirow{3}{*}{ winter } & GUD to $\mathrm{T}_{\max }$ & $\mathbf{- 0 . 0 9}$ & 0.04 \\
& GUD to $\mathrm{T}_{\min }$ & -0.02 & $\mathbf{0 . 0 4}$ \\
& GUD to precipitation & -0.40 & 0.33 \\
\hline \multirow{3}{*}{ spring } & GUD to $\mathrm{T}_{\max }$ & $\mathbf{- 0 . 1 0}$ & 0.03 \\
& GUD to $\mathrm{T}_{\min }$ & -0.04 & 0.02 \\
& GUD to precipitation & $\mathbf{- 0 . 2 0}$ & 0.40 \\
\hline
\end{tabular}

${ }^{1}$ The unit is days $/{ }^{\circ} \mathrm{C}$ (sensitivity of GUD to $\mathrm{T}_{\max }$ or $\mathrm{T}_{\min }$ ) or days $/ \mathrm{mm}$ (sensitivity of GUD to precipitation).

Sensitivity analysis was conducted for vegetation GUD of LM to $T_{\max }, T_{\min }$, and precipitation in March, April, and May (Table 13). In the UM region, only $\mathrm{T}_{\min }$ in March and May had much more influence on GUD. $T_{\min }$ in March had more influence on GUD than that in May. In March, the sensitivity of GUD to $\mathrm{T}_{\min }\left(-0.14\right.$ days $\left./{ }^{\circ} \mathrm{C}\right)$ was far more than the sensitivity of GUD to $\mathrm{T}_{\min }\left(0.02\right.$ days $\left./{ }^{\circ} \mathrm{C}\right)$ in May. Unlike the whole spring, precipitation has little influence on GUD in March, April, and May. 
Table 13. Sensitivity of GUD to meteorological indicators of LM in March, April, and May.

\begin{tabular}{cccc}
\hline $\begin{array}{c}\text { Sensitivity of GUD to } \\
\text { Meteorological Indicators }\end{array}$ & $\begin{array}{c}\text { Significant Negative } \\
(\boldsymbol{p}<\mathbf{0 . 0 5 )}\end{array}$ & $\begin{array}{c}\text { Significant Positive } \\
(\boldsymbol{p}<\mathbf{0 . 0 5})\end{array}$ \\
\hline \multirow{3}{*}{ March } & GUD to $\mathrm{T}_{\max }$ & -0.20 & 0.09 \\
& GUD to $\mathrm{T}_{\min }$ & $-\mathbf{0 . 1 4}$ & 0.09 \\
& GUD to precipitation & -0.10 & 0.34 \\
\hline \multirow{3}{*}{ April } & GUD to $\mathrm{T}_{\max }$ & -0.16 & 0.04 \\
& GUD to $\mathrm{T}_{\min }$ & -0.05 & 0.02 \\
& GUD to precipitation & -0.23 & 0.56 \\
\hline \multirow{3}{*}{ May } & GUD to $\mathrm{T}_{\max }$ & -0.02 & 0.02 \\
& GUD to $\mathrm{T}_{\min }$ & -0.02 & $\mathbf{0 . 0 2}$ \\
& GUD to precipitation & -0.08 & 0.28 \\
\hline
\end{tabular}

${ }^{1}$ The unit is days $/{ }^{\circ} \mathrm{C}$ (sensitivity of GUD to $\mathrm{T}_{\max }$ or $\mathrm{T}_{\min }$ ) or days $/ \mathrm{mm}$ (sensitivity of GUD to precipitation)

\section{Discussion}

\subsection{Comparisons with Previous Studies}

The mean GUD across the Hulun Buir area was DOY 113.1; this result was similar to the study in the temperate grasslands of China [24] and the study in Hulun Buir grassland area [38]. The mean GUD trend overall was -3.1 days/decade from 2001-2018. The study in the temperate grasslands of China showed that the GUD significantly advanced at a rate of 1.84 days/decade from 1982 to 2015 [24,47]. Our GUD trend results have the same advanced trend, and the strength of the advance is slightly higher. Global warming is causing temperatures to rise, and we found large differences in the extent of the Tmax and Tmin changes; however, these changes are not significant.

The research results of Peng et al. [50] pointed out that the $T_{\min }$ of the growing season in the whole temperate arid region on Northern Hemisphere was positively correlated with NDVI. TS in Hulun Buir is semi-arid and the driest area in the whole region. $\mathrm{T}_{\min }$ in March promoted green-up, which is consistent with the Peng et al. [50] study. Shen et al. pointed out that precipitation in spring have a strong impact on the GUD in temperate grasslands. Our results show in TS, that the GUD has the greatest sensitivity to precipitation.

Peng et al. [50] also showed that in the past three decades, the higher $\mathrm{T}_{\max }$ in spring were significantly positively correlated with NDVI. In Hulun Buir, GUD of TMS, LM, and $\mathrm{UM}$ was significantly negatively correlated with $\mathrm{T}_{\max }$ in spring, and most of the areas were distributed in the northern part of the region higher than $50^{\circ} \mathrm{N}$ (which was in the sub-humid and humid region). The increase in $\mathrm{T}_{\max }$ can promote the growth of vegetation and advance GUD.

\subsection{Results in Terms of Plant Physiology}

Plant species may respond differently to warming and soil water supply, depending on their morphological, physiological, and lifecycle characteristics [51-53]. In arid and semi-arid ecosystems, warming causes water stress in shallow soils, which reduces shallowroot plant growth and development, allowing plants to make more efficient use of topsoil water [54].

Nocturnal warming may also affect the photosynthetic activity of vegetation through different mechanisms. First, nighttime warming can be achieved by increasing carbohydrate consumption in leaves at night [55,56], stimulating photosynthesis in plants [55]. Second, nighttime also negatively affects plant photosynthesis by increasing autotrophic respiration [50], but nighttime conditions do not affect photosynthesis itself. Field warming experiments in arid temperate grassland regions of China showed that nocturnal warming increased plant photosynthesis by about $20 \%$ [56]. Global warming promotes vegetation photosynthesis and shifts in phenology during spring in the Northern Hemisphere $[3,57,58]$. 


\subsection{Factors Affecting the Spatial Variation of Sensitivity}

From the perspective of geographical location and meteorological conditions, the semi-arid areas in southwest China, including the north of New Barag Left Banner and the west of Chen Barag Banner, have relatively high temperatures and low precipitation. The increase in $\mathrm{T}_{\min }$ can significantly advance GUD, whereas $\mathrm{T}_{\max }$ plays the opposite role. In the central and eastern regions, $T_{\max }$ showed a negative correlation with GUD, and a significant correlation was mainly distributed in the northernmost region, where the temperature was lower and the precipitation was less. The increase in $\mathrm{T}_{\max }$ was beneficial to the GUD.

The temperature is highest and the precipitation lowest in New Barag Right Banner. The proportion of partial correlation between the spring precipitation and GUD is significantly higher than that of $\mathrm{T}_{\max }$ and $\mathrm{T}_{\min }$, and GUD is greatly affected by spring precipitation. Similarly, in the northwest of New Barag Left Banner and the west of Chen Barag Banner, there was a significant negative correlation between GUD and $\mathrm{T}_{\min }$, but a significant positive correlation between GUD and $T_{\max }$. The increase in $\mathrm{T}_{\max }$ inhibited vegetation growth, while the increase in $T_{\min }$ was beneficial to GUD. This was consistent with the study of Peng et al. [50] that NDVI was significantly positively correlated with $\mathrm{T}_{\text {min }}$ in the Northern Hemisphere where most of the studied regions were arid and semi-arid. The increase in $\mathrm{T}_{\min }$ could improve the biomass in arid temperate grassland areas of China. The northern region is in the sub-humid region with lower temperatures and relatively more precipitation. $T_{\max }$ plays a role in promoting vegetation green-up, while $\mathrm{T}_{\min }$ does the opposite, which is consistent with the study of Piao et al. [26]. Photosynthesis of plants occurs in the daytime and is directly affected by $\mathrm{T}_{\max }$.

\section{Conclusions}

In the present study, remote sensing and meteorological data were used to investigate the sensitivity of GUD to meteorological indicators in the Hulun Buir grasslands of China during the winter and spring warming periods between 2001 and 2018. Our analysis indicated that the average GUD across the whole area was DOY 113. The mean GUD trend was -3.1 days/decade and the $25 \%$ region advanced significantly. $T_{\max }$ and $\mathrm{T}_{\min }$ tended to decrease during winter over the period studied $(p>0.05)$. In spring, $\mathrm{T}_{\max }$ mainly has an increasing trend $(p>0.05)$ and $\mathrm{T}_{\min }$ also has an increasing trend $(p>0.05)$. Precipitation mainly shows no significant $(p>0.05)$ change trend and the trend range was $\pm 10 \mathrm{~mm} /$ decade. In TS, GUD has the greatest sensitivity to spring precipitation and April precipitation. In TMS, UM, and LM, the GUDs have the greatest sensitivity to $T_{\min }$ in March and precipitation has little impact on GUD.

Author Contributions: Conceptualization, J.G. and X.Y.; software, J.G. and M.Z.; formal analysis, J.G., F.C. and A.C.; data curation, J.G., X.X. and D.Y.; writing-original draft preparation, J.G.; writingreview and editing, J.G., X.Y., W.J., P.Y., L.J. and B.X.; funding acquisition, X.Y. All authors have read and agreed to the published version of the manuscript.

Funding: This study was supported by the Inner Mongolia Science and Technology Major Project (2021ZD0011-04), the National Natural Science Foundation of China (41571105) and the National Key Research and Development Program of China (2017YFC0506504).

Data Availability Statement: Not applicable.

Conflicts of Interest: The authors declare no conflict of interest. The funders had no role in the design of the study; in the collection, analyses, or interpretation of data; in the writing of the manuscript; or in the decision to publish the results. 


\begin{tabular}{|c|c|}
\hline \multicolumn{2}{|c|}{ Abbreviations } \\
\hline GUD & green-up date \\
\hline Tmax & daily maximum temperature \\
\hline Tmin & daily minimum temperature \\
\hline TS & temperate steppe \\
\hline TMS & temperate meadow steppe \\
\hline UM & upland meadow \\
\hline LM & lowland meadow \\
\hline MODIS & Moderate Resolution Imaging Spectroradiometer \\
\hline NASA & National Aeronautics and Space Administration \\
\hline NDPI & normalized difference phenology index \\
\hline DOY & day of year \\
\hline
\end{tabular}

\section{References}

1. IPCC. Climate Change 2013: The Physical Science Basis. Contribution of Working Group I to the Fifth Assessment Report of the Intergovernmental Panel on Climate Change; Stocker, T.F., Qin, D., Plattner, G.-K., Tignor, M., Allen, S.K., Boschung, J., Nauels, A., Xia, Y., Bex, V., Midgley, P.M., Eds.; Cambridge University Press: Cambridge, UK, 2013; p. 188.

2. Lieth, H. Purposes of a Phenology Book; Springer: Berlin/Heidelberg, Germany, 1974. [CrossRef]

3. Myneni, R.B.; Keeling, C.D.; Tucker, C.J.; Asrar, G.; Nemani, R.R. Increased plant growth in the northern high latitudes from 1981 to 1991. Nature 1997, 386, 698-702. [CrossRef]

4. Sparks, T.H.; Menzel, A. Observed changes in seasons: An overview. Int. J. Climatol. 2002, 22, 1715-1725. [CrossRef]

5. Thackeray, S.J.; Henrys, P.A.; Hemming, D.; Bell, J.R.; Botham, M.S.; Burthe, S.; Helaouet, P.; Johns, D.G.; Jones, I.D.; Leech, D.I.; et al. Phenological sensitivity to climate across taxa and trophic levels. Nature 2016, 535, 241-245. [CrossRef] [PubMed]

6. Yang, L.H.; Rudolf, V.H. Phenology, ontogeny and the effects of climate change on the timing of species interactions. Ecol. Lett. 2010, 13, 1-10. [CrossRef]

7. Kharouba, H.M.; Ehrlen, J.; Gelman, A.; Bolmgren, K.; Allen, J.M.; Travers, S.E.; Wolkovich, E.M. Global shifts in the phenological synchrony of species interactions over recent decades. Proc. Natl. Acad. Sci. USA 2018, 115, 5211-5216. [CrossRef]

8. Renner, S.S.; Zohner, C.M. Climate Change and Phenological Mismatch in Trophic Interactions Among Plants, Insects, and Vertebrates. Annu. Rev. Ecol. Evol. Syst. 2018, 49, 165-182. [CrossRef]

9. Wolkovich, E.M.; Cook, B.I.; Allen, J.M.; Crimmins, T.M.; Betancourt, J.L.; Travers, S.E.; Pau, S.; Regetz, J.; Davies, T.J.; Kraft, N.J.; et al. Warming experiments underpredict plant phenological responses to climate change. Nature 2012, 485, 494-497. [CrossRef]

10. Menzel, A.; Sparks, T.H.; Estrella, N.; Koch, E.; Aasa, A.; Ahas, R.; Alm-Kubler, K.; Bissolli, P.; Braslavska, O.; Briede, A.; et al. European phenological response to climate change matches the warming pattern. Glob. Chang. Biol. 2006, 12, 1969-1976. [CrossRef]

11. Lapenis, A.; Henry, H.; Vuille, M.; Mower, J. Climatic factors controlling plant sensitivity to warming. Clim. Chang. 2014, 122, 723-734. [CrossRef]

12. Still, C. As different as night and day. Nature 2013, 501,39-40. [CrossRef]

13. Diez, J.M.; Ibanez, I.; Miller-Rushing, A.J.; Mazer, S.J.; Crimmins, T.M.; Crimmins, M.A.; Bertelsen, C.D.; Inouye, D.W. Forecasting phenology: From species variability to community patterns. Ecol. Lett. 2012, 15, 545-553. [CrossRef] [PubMed]

14. Pau, S.; Wolkovich, E.M.; Cook, B.I.; Davies, T.J.; Kraft, N.J.B.; Bolmgren, K.; Betancourt, J.L.; Cleland, E.E. Predicting phenology by integrating ecology, evolution and climate science. Glob. Chang. Biol. 2011, 17, 3633-3643. [CrossRef]

15. Zhang, X.Y.; Friedl, M.A.; Schaaf, C.B.; Strahler, A.H. Climate controls on vegetation phenological patterns in northern mid- and high latitudes inferred from MODIS data. Glob. Chang. Biol. 2004, 10, 1133-1145. [CrossRef]

16. Cleland, E.E.; Chiariello, N.R.; Loarie, S.R.; Mooney, H.A.; Field, C.B. Diverse responses of phenology to global changes in a grassland ecosystem. Proc. Natl. Acad. Sci. USA 2006, 103, 13740-13744. [CrossRef] [PubMed]

17. Penuelas, J.; Rutishauser, T.; Filella, I. Ecology. Phenology feedbacks on climate change. Science 2009, 324, 887-888. [CrossRef] [PubMed]

18. Parmesan, C.; Yohe, G. A globally coherent fingerprint of climate change impacts across natural systems. Nature 2003, 421, 37-42. [CrossRef]

19. Gonsamo, A.; Chen, J.M.; D'Odorico, P. Deriving land surface phenology indicators from $\mathrm{CO}_{2}$ eddy covariance measurements. Ecol. Indic. 2013, 29, 203-207. [CrossRef]

20. Zheng, Z.T.; Zhu, W.Q.; Chen, G.S.; Jiang, N.; Fan, D.Q.; Zhang, D.H. Continuous but diverse advancement of spring-summer phenology in response to climate warming across the Qinghai-Tibetan Plateau. Agric. For. Meteorol. 2016, 223, 194-202. [CrossRef]

21. Ji, L.; Peters, A.J. A spatial regression procedure for evaluating the relationship between AVHRR-NDVI and climate in the northern Great Plains. Int. J. Remote Sens. 2004, 25, 297-311. [CrossRef]

22. Xu, X.; Riley, W.J.; Koven, C.D.; Jia, G. Observed and Simulated Sensitivities of Spring Greenup to Preseason Climate in Northern Temperate and Boreal Regions. J. Geophys. Res. Biogeosci. 2018, 123, 60-78. [CrossRef] 
23. Fu, Y.H.; Liu, Y.; De Boeck, H.J.; Menzel, A.; Nijs, I.; Peaucelle, M.; Penuelas, J.; Piao, S.; Janssens, I.A. Three times greater weight of daytime than of night-time temperature on leaf unfolding phenology in temperate trees. New Phytol. 2016, 212, 590-597. [CrossRef] [PubMed]

24. Shen, X.; Liu, B.; Henderson, M.; Wang, L.; Wu, Z.; Wu, H.; Jiang, M.; Lu, X. Asymmetric effects of daytime and nighttime warming on spring phenology in the temperate grasslands of China. Agric. For. Meteorol. 2018, 259, 240-249. [CrossRef]

25. Meng, L.; Zhou, Y.Y.; Li, X.; Asrar, G.R.; Mao, J.F.; Wanamaker, A.D.; Wang, Y.Q. Divergent responses of spring phenology to daytime and nighttime warming. Agric. For. Meteorol. 2020, 281, 107832. [CrossRef]

26. Piao, S.; Tan, J.; Chen, A.; Fu, Y.H.; Ciais, P.; Liu, Q.; Janssens, I.A.; Vicca, S.; Zeng, Z.; Jeong, S.J.; et al. Leaf onset in the northern hemisphere triggered by daytime temperature. Nat. Commun. 2015, 6, 6911. [CrossRef]

27. Vitasse, Y.; Delzon, S.; Dufrêne, E.; Pontailler, J.-Y.; Louvet, J.-M.; Kremer, A.; Michalet, R. Leaf phenology sensitivity to temperature in European trees: Do within-species populations exhibit similar responses? Agric. For. Meteorol. 2009, 149, 735-744. [CrossRef]

28. Shen, M.; Tang, Y.; Chen, J.; Yang, X.; Wang, C.; Cui, X.; Yang, Y.; Han, L.; Li, L.; Du, J.; et al. Earlier-season vegetation has greater temperature sensitivity of spring phenology in northern hemisphere. PLoS ONE 2014, 9, e88178. [CrossRef]

29. Cong, N.; Wang, T.; Nan, H.; Ma, Y.; Wang, X.; Myneni, R.B.; Piao, S. Changes in satellite-derived spring vegetation green-up date and its linkage to climate in China from 1982 to 2010: A multimethod analysis. Glob. Chang. Biol. 2013, 19, 881-891. [CrossRef]

30. Wu, C.Y.; Gonsamo, A.; Chen, J.M.; Kurz, W.A.; Price, D.T.; Lafleur, P.M.; Jassal, R.S.; Dragoni, D.; Bohrer, G.; Gough, C.M.; et al. Interannual and spatial impacts of phenological transitions, growing season length, and spring and autumn temperatures on carbon sequestration: A North America flux data synthesis. Glob. Planet Chang. 2012, 92-93, 179-190. [CrossRef]

31. Rossi, S.; Isabel, N. Bud break responds more strongly to daytime than night-time temperature under asymmetric experimental warming. Glob. Chang. Biol. 2017, 23, 446-454. [CrossRef]

32. Shen, M.G.; Piao, S.L.; Chen, X.Q.; An, S.; Fu, Y.S.H.; Wang, S.P.; Cong, N.; Janssens, I.A. Strong impacts of daily minimum temperature on the green-up date and summer greenness of the Tibetan Plateau. Glob. Chang. Biol. 2016, 22, 3057-3066. [CrossRef]

33. Crimmins, T.M.; Crimmins, M.A.; David Bertelsen, C. Complex responses to climate drivers in onset of spring flowering across a semi-arid elevation gradient. J. Ecol. 2010, 98, 1042-1051. [CrossRef]

34. Julitta, T.; Cremonese, E.; Migliavacca, M.; Colombo, R.; Galvagno, M.; Siniscalco, C.; Rossini, M.; Fava, F.; Cogliati, S.; Morra di Cella, U.; et al. Using digital camera images to analyse snowmelt and phenology of a subalpine grassland. Agric. For. Meteorol. 2014, 198-199, 116-125. [CrossRef]

35. Wu, X.; Liu, H. Consistent shifts in spring vegetation green-up date across temperate biomes in China, 1982-2006. Glob. Chang. Biol. 2013, 19, 870-880. [CrossRef] [PubMed]

36. Tao, F.; Yokozawa, M.; Zhang, Z.; Hayashi, Y.; Ishigooka, Y. Land surface phenology dynamics and climate variations in the North East China Transect (NECT), 1982-2000. Int. J. Remote Sens. 2008, 29, 5461-5478. [CrossRef]

37. Sun, Z.; Wang, Q.; Xiao, Q.; Batkhishig, O.; Watanabe, M. Diverse Responses of Remotely Sensed Grassland Phenology to Interannual Climate Variability over Frozen Ground Regions in Mongolia. Remote Sens. 2014, 7, 360-377. [CrossRef]

38. Guo, J.; Yang, X.; Chen, F.; Niu, J.; Luo, S.; Zhang, M.; Jin, Y.; Shen, G.; Chen, A.; Xing, X.; et al. Examining Relationships between Heat Requirement of Remotely Sensed Green-Up Date and Meteorological Indicators in the Hulun Buir Grassland. Remote Sens. 2021, 13, 1044. [CrossRef]

39. Wang, C.; Chen, J.; Wu, J.; Tang, Y.H.; Shi, P.J.; Black, T.A.; Zhu, K. A snow-free vegetation index for improved monitoring of vegetation spring green-up date in deciduous ecosystems. Remote Sens. Environ. 2017, 196, 1-12. [CrossRef]

40. He, J.; Yang, K.; Tang, W.; Lu, H.; Qin, J.; Chen, Y.; Li, X. The first high-resolution meteorological forcing dataset for land process studies over China. Sci. Data 2020, 7, 25. [CrossRef]

41. Mann, H.B. Nonparametric tests against trend. Econometrica 1945, 45, 245-259. [CrossRef]

42. Kendall, M.G. Rank Correlation Methods; Griffin: London, UK, 1948. [CrossRef]

43. Sen, P.K. Estimates of the Regression Coefficient Based on Kendall's Tau. J. Am. Stat. Assoc. 1968, 63, 1379-1389. [CrossRef]

44. Zhang, D.; Geng, X.; Chen, W.; Fang, L.; Yao, R.; Wang, X.; Zhou, X. Inconsistency of Global Vegetation Dynamics Driven by Climate Change: Evidences from Spatial Regression. Remote Sens. 2021, 13, 3442. [CrossRef]

45. Nouri, M.; Homaee, M. Spatiotemporal changes of snow metrics in mountainous data-scarce areas using reanalyses. J. Hydrol. 2021, 603, 126858. [CrossRef]

46. Ruan, Y.; Zhang, X.; Xin, Q.; Qiu, Y.; Sun, Y. Prediction and Analysis of Lake Ice Phenology Dynamics Under Future Climate Scenarios Across the Inner Tibetan Plateau. J. Geophys. Res. Atmos. 2020, 125, e2020JD033082. [CrossRef]

47. Fu, Y.H.; Zhou, X.; Li, X.; Zhang, Y.; Geng, X.; Hao, F.; Zhang, X.; Hanninen, H.; Guo, Y.; De Boeck, H.J.; et al. Decreasing control of precipitation on grassland spring phenology in temperate China. Glob. Ecol. Biogeogr. 2020, 30, 490-499. [CrossRef]

48. Fu, Y.H.; Piao, S.; Vitasse, Y.; Zhao, H.; De Boeck, H.J.; Liu, Q.; Yang, H.; Weber, U.; Hanninen, H.; Janssens, I.A. Increased heat requirement for leaf flushing in temperate woody species over 1980-2012: Effects of chilling, precipitation and insolation. Glob. Chang. Biol. 2015, 21, 2687-2697. [CrossRef]

49. Shen, M.; Cong, N.; Cao, R. Temperature sensitivity as an explanation of the latitudinal pattern of green-up date trend in Northern Hemisphere vegetation during 1982-2008. Int. J. Climatol. 2015, 35, 3707-3712. [CrossRef]

50. Peng, S.; Piao, S.; Ciais, P.; Myneni, R.B.; Chen, A.; Chevallier, F.; Dolman, A.J.; Janssens, I.A.; Penuelas, J.; Zhang, G.; et al. Asymmetric effects of daytime and night-time warming on Northern Hemisphere vegetation. Nature 2013, 501, 88-92. [CrossRef] 
51. Price, M.V.; Waser, N.M. Effects of experimental warming on plant reproductive phenology in a subalpine meadow. Ecology 1998, 79, 1261-1271. [CrossRef]

52. Dunne, J.A.; Harte, J.; Taylor, K.J. Subalpine meadow flowering phenology responses to climate change: Integrating experimental and gradient methods. Ecol. Monogr. 2003, 73, 69-86. [CrossRef]

53. Root, T.L.; Price, J.T.; Hall, K.R.; Schneider, S.H.; Rosenzweig, C.; Pounds, J.A. Fingerprints of global warming on wild animals and plants. Nature 2003, 421, 57-60. [CrossRef]

54. Williams, A.P.; Allen, C.D.; Macalady, A.K.; Griffin, D.; Woodhouse, C.A.; Meko, D.M.; Swetnam, T.W.; Rauscher, S.A.; Seager, R.; Grissino-Mayer, H.D.; et al. Temperature as a potent driver of regional forest drought stress and tree mortality. Nat. Clim. Chang. 2013, 3, 292-297. [CrossRef]

55. Beier, C.; Emmett, B.; Gundersen, P.; Tietema, A.; Penuelas, J.; Estiarte, M.; Gordon, C.; Gorissen, A.; Llorens, L.; Roda, F.; et al. Novel approaches to study climate change effects on terrestrial ecosystems in the field: Drought and passive nighttime warming. Ecosystems 2004, 7, 583-597. [CrossRef]

56. Wan, S.; Xia, J.; Liu, W.; Niu, S. Photosynthetic overcompensation under nocturnal warming enhances grassland carbon sequestration. Ecology 2009, 90, 2700-2710. [CrossRef] [PubMed]

57. Piao, S.L.; Friedlingstein, P.; Ciais, P.; Viovy, N.; Demarty, J. Growing season extension and its impact on terrestrial carbon cycle in the Northern Hemisphere over the past 2 decades. Glob. Biogeochem. Cycles 2007, 21, GB3018. [CrossRef]

58. Tucker, C.J.; Slayback, D.A.; Pinzon, J.E.; Los, S.O.; Myneni, R.B.; Taylor, M.G. Higher northern latitude normalized difference vegetation index and growing season trends from 1982 to 1999. Int. J. Biometeorol. 2001, 45, 184-190. [CrossRef] [PubMed] 